\title{
Cross-shelf transport of pink shrimp larvae: interactions of tidal currents, larval vertical migrations and internal tides
}

\author{
Maria M. Criales ${ }^{1, *}$, Joan A. Browder ${ }^{2}$, Christopher N. K. Mooers $^{1}$, \\ Michael B. Robblee ${ }^{3}$, Hernando Cardenas ${ }^{1}$, Thomas L. Jackson ${ }^{2}$ \\ ${ }^{1}$ Rosenstiel School of Marine and Atmospheric Science, University of Miami, 4600 Rickenbacker Causeway, Miami, \\ Florida 33149, USA \\ ${ }^{2}$ NOAA Fisheries, Southeast Fisheries Science Center, 75 Virginia Beach Drive, Miami, Florida 33149, USA \\ ${ }^{3}$ US Geological Survey, Center for Water and Restoration Studies, 3110 SW 9th Avenue, Ft Lauderdale, Florida 33315, USA
}

\begin{abstract}
Transport and behavior of pink shrimp Farfantepenaeus duorarum larvae were investigated on the southwestern Florida (SWF) shelf of the Gulf of Mexico between the Dry Tortugas spawning grounds and Florida Bay nursery grounds. Stratified plankton samples and hydrographic data were collected at $2 \mathrm{~h}$ intervals at 3 stations located on a cross-shelf transect. At the Marquesas station, midway between Dry Tortugas and Florida Bay, internal tides were recognized by anomalously cool water, a shallow thermocline with strong density gradients, strong current shear, and a high concentration of pink shrimp larvae at the shallow thermocline. Low Richardson numbers occurred at the pycnocline depth, indicating vertical shear instability and possible turbulent transport from the lower to the upper layer where myses and postlarvae were concentrated. Analysis of vertically stratified plankton suggested that larvae perform vertical migrations and the specific behavior changes ontogenetically; protozoeae were found deeper than myses, and myses deeper than postlarvae. Relative concentrations of protozoea in the upper, middle and bottom layers were consistent with a diel vertical migration, whereas that of postlarvae and myses were consistent with the semidiurnal tides in phase with the flood tide. Postlarvae, the shallowest dwellers that migrate with a semidiurnal periodicity, experienced the largest net onshore flux and larval concentrations were highly correlated with the cross-shelf current. These results provide the first evidence of an onshore tidal transport (a type of selective tidal stream transport, STST), in decapod larvae migrating in continental shelf waters offshore, ca. $100 \mathrm{~km}$ from the coast and at a depth of $20 \mathrm{~m}$, while approaching the coastal nursery grounds. Longer time series would be necessary to establish whether internal tides play any role in the larval onshore transport of this species and determine if the STST is the dominant onshore transport mechanism.
\end{abstract}

KEY WORDS: Selective tidal transport • Pink shrimp larval behavior · Internal tides . Farfantepenaeus duorarum

Resale or republication not permitted without written consent of the publisher

\section{INTRODUCTION}

Most coastal species of fishes and invertebrates spawn offshore in shelf waters and early life stages migrate to coastal estuarine nursery grounds. Although little is known about the ecological coupling of estuaries and the coastal ocean, progress has been made in understanding transport mechanisms of im- portant species that connect offshore and coastal grounds (for review see Shanks 1995). The dominant mechanisms that may yield successful cross-shelf transport include wind-driven Ekman transport, upwelling fronts, moving frontal systems, countercurrents generated by coastal eddies, coastal boundary layers and non-linear internal tides and bores (e.g. Shanks 1995, 2006, Pineda 1999, Epifanio \& Garvine 
2001, Sponaugle et al. 2005). Another potential mechanism for cross-shelf transport includes tides in association with a vertical movement behavior.

Selective tidal stream transport (STST) is an important mechanism by which planktonic organisms use vertical differences of water velocity in a shear current system to promote transport in an 'appropriate' direction (for review see Forward \& Tankersley 2001, Queiroga \& Blanton 2005). Decapod larvae that spend some portion of their life cycle in estuarine systems use STST to promote transport, resulting in retention, export or reinvasion (Shanks 1995). The STST has been implicated in transport of larvae and postlarvae entering coastal nursery grounds, but not in cross-shelf transport on shelf waters. A STST has been identified in postlarvae of penaeid shrimps including the pink shrimp Farfantepenaeus duorarum (i.e. Rothlisberg et al. 1996, Criales et al. 2006), crab megalopae (for review see Forward \& Tankersley 2001, Queiroga \& Blanton 2005) and estuarine fish larvae (i.e. Rowe \& Epifanio 1994). In order to immigrate to or remain within the estuary, planktonic larvae need to have some kind of behavioral adaptation to overcome the opposite flux of the water associated with the tide. A growing body of laboratory and field observations suggests that vertical displacements are not a passive phenomenon, but that larval behavior indeed influences this process (e.g. Forward et al. 2003). Environmental factors involved in controlling the vertical migrations are light, pressure and gravity (e.g Sulkin 1984), but salinity, temperature and turbulence also affect behavior (e.g Welch \& Forward 2001). Most of these factors change cyclically, and larvae respond with cyclical vertical movements.

The pink shrimp is an important species in southern Florida; it supports the multimillion dollar Tortugas fishery on the southwestern Florida (SWF) shelf in the vicinity of Dry Tortugas and Key West and serves as an important prey species in Florida Bay, the principal inshore nursery habitat (Browder et al. 2002) (Fig. 1). As with most coastal-estuarine species, the spawning and nursery grounds of the pink shrimp in Florida are spatially separated. Spawning areas are northeast of the Dry Tortugas and juveniles occupy nursery grounds in Florida Bay about $150 \mathrm{~km}$ to the east-northeast (Roberts 1986). Larval development is rapid, passing through 5 nauplii, 3 protozoeae, and 3 myses in about $15 \mathrm{~d}$
(Dobkin 1961), and 3 to 6 additional planktonic postlarval stages in another $15 \mathrm{~d}$ (Ewald 1965). Two main pathways have been hypothesized for pink shrimp larvae migrating from Dry Tortugas to Florida Bay: (1) larvae drift south-southeast downstream with the Florida Current front and enter Florida Bay through the tidal inlets of the middle Florida Keys (Munro et al. 1968, Criales et al. 2003); and (2) larvae move northeast across the SWF shelf and enter Florida Bay at its northwestern boundary (Jones et al. 1970, Criales et al. 2006). Transport via Florida Current-Florida Keys inlets was, until recently, the most widely recognized larval route because Ekman transport generated by winds and coastal countercurrent flow generated by cyclonic eddies may provide favorable onshore transport mechanisms along the Florida Keys coast (Lee \& Williams 1999, Yeung et al. 2001). Nevertheless, recent results from a comparative study on these 2 migration pathways indicated that the greatest postlarval influx ( $>70 \%$ ) occurred at the northwestern border of Florida Bay, suggesting a viable east-northeast transport across the SWF shelf (Criales et al. 2006). Florida Bay lies at the southern end of the Florida peninsula and its western border connects directly with the inner SWF shelf.

Winds in southern Florida are seasonal; weak winds primarily from the southeast dominate in summer, stronger winds from the northeast in the fall, and moderate to strong winds from the east to northeast in the

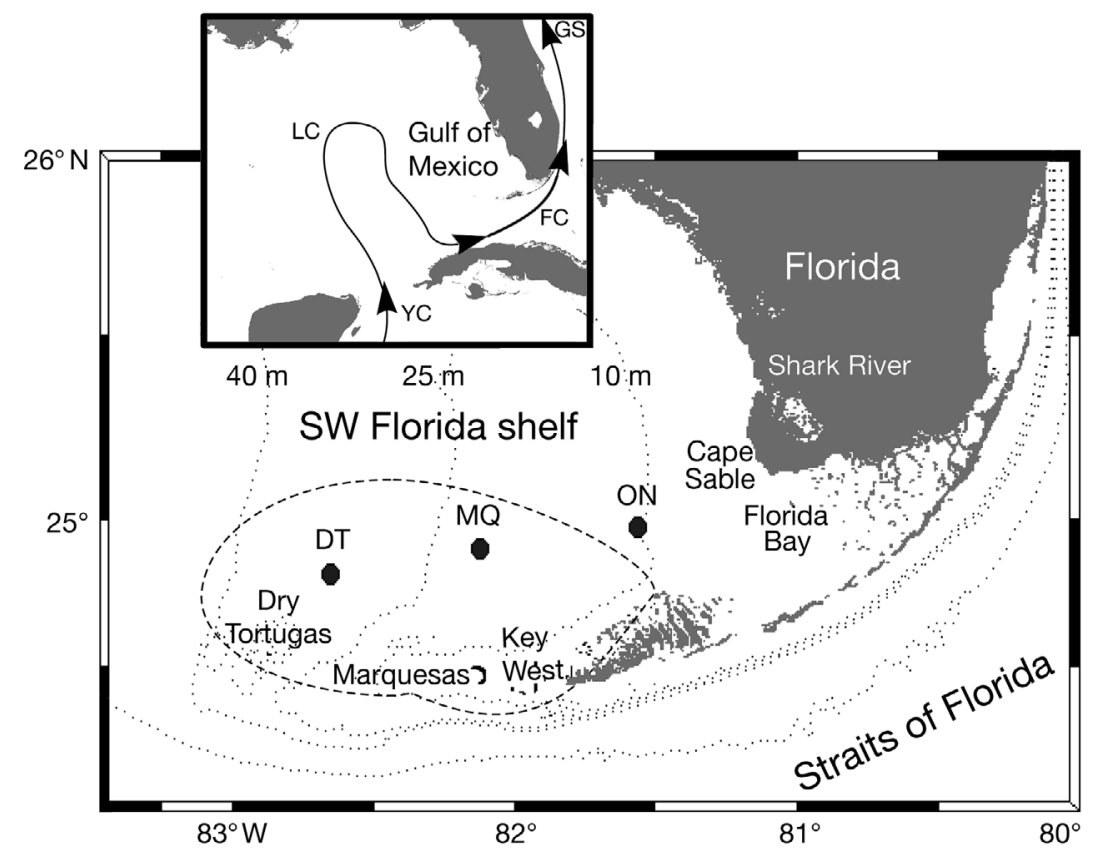

Fig. 1. Study area showing the 3 sampling stations (DT $=$ Dry Tortugas, $M Q=$ Marquesas, $\mathrm{ON}=$ Onshore). The area enclosed by dashed line represents the Tortugas fishing grounds of pink shrimp Farfantepenaeus duorarum. The inset map indicates major currents in the Gulf of Mexico and off the coast of Florida. $\mathrm{YC}=$ Yucatan Current, $\mathrm{LC}=$ Loop Current, $\mathrm{FC}=$ Florida Current, GS = Gulf Stream 
winter and spring (Lee \& Williams 1999). The ocean circulation around the Dry Tortugas is highly dynamic and is affected by the interaction of the Loop-Florida Current system and warm core (anticyclonic) and cool core (cyclonic) eddies, common phenomena associated with the Loop Current front (Fratantoni et al. 1998). Interactions with the Loop Current on the SWF shelf are sporadic and eddies may not play a major role in dispersal of pink shrimp larvae because eddies usually form southwest of the Dry Tortugas (Lee et al. 1994) and the principal nursery ground is northeast of the Dry Tortugas. Circulation on the SWF shelf is forced mainly by tidal currents, winds and buoyancy fluxes (Weisberg et al. 1996). Tidal currents are strong in the cross-shelf direction; in contrast, subtidal flows are weak and mainly along-shore as a direct response to wind events (Lee et al. 2002). Tides on the SWF shelf are mixed with contributions from both diurnal and semidiurnal components (Smith 2000). Freshwater discharges from the Shark River affect a broad area of the SWF shelf (Lee et al. 2002). Vertical stratification of the water column occurs in spring and summer as a response to variations in wind-mixing, heating and river runoff (He \& Weisberg 2002).

Simulations of transport derived from a Lagrangian (horizontal) model coupled with larval vertical behaviors identified STST as a viable transport mechanism for pink shrimp larvae across the SWF shelf (Criales et al. 2006). Planktonic stages, which migrate vertically to position themselves near the surface during the flood tide, could consistently travel between 100 and $200 \mathrm{~km}$ in $30 \mathrm{~d}$ across the wide SWF shelf, and hypothetically $85 \%$ of the population could travel 150 $\mathrm{km}$. With this mechanism planktonic stages take advantage of the strong eastward surface flow that dominates the SWF Shelf. A STST behavior previously has been identified in pink shrimp postlarvae entering estuarine nursery grounds, but not in earlier stages during their onshore migration across the shelf. Other potential mechanisms of cross-shelf transport on the SWF shelf, such as non-linear internal waves and bores, Ekman transport or coastal boundary layers, have not been identified. Which of these mechanisms, if any, occur on the SWF shelf and transport larvae to near-shore areas is unknown. It also is unclear if similar mechanisms regulate transport throughout the journey from offshore spawning areas to estuaries or if estuarine ingress of coastal organisms is more than a single stage process. This research was conducted to determine (1) potential transport mechanisms on the SWF shelf, (2) behavior of early planktonic stages during their migration across the SWF shelf and possible environmental cues associated with the behavior, and (3) implications of behavioral patterns for transport.

\section{MATERIALS AND METHODS}

Field sampling. Three stations on the SWF shelf, separated from each other by $60 \mathrm{~km}$, were sampled along a cross-shelf transect between the Dry Tortugas and Florida Bay, on board the RV 'Gandy' on July 2-5, 2004 (Fig. 1). The Dry Tortugas (DT) station, the farthest offshore, was selected for its proximity to the known spawning grounds of pink shrimp (Jones et al. 1970, Roberts 1986) about $30 \mathrm{~km}$ northeast of the Dry Tortugas at a depth of $30 \mathrm{~m}$. The Marquesas (MQ) station was $30 \mathrm{~km}$ north of Marquesas at a depth of $20 \mathrm{~m}$, and the onshore (ON) station was about $40 \mathrm{~km}$ southwest of Cape Sable on the western border of Florida Bay at a depth of $10 \mathrm{~m}$. Sampling was conducted during the full moon in accordance with previous results that showed the highest spawning activity of pink shrimp females occurred between the full and last quarter moon (Munro et al. 1968). A $300 \mathrm{kHz}$ bottom mounted Workhorse Acoustic Doppler current profiler (ADCP) was deployed at the $\mathrm{DT}$ and $\mathrm{MQ}$ stations at depths of 30 and $20 \mathrm{~m}$, respectively, to measure currents with vertical bin sizes of $1 \mathrm{~m}$.

At each station stratified plankton samples were collected at 3 fixed depths with a $1 \mathrm{~m}^{2}$ Tucker trawl net (333 $\mu \mathrm{m}$ mesh). The Tucker trawl net was equipped with 3 nets towed at a speed of 1.5 to 2.5 knots $\left(0.8-1.3 \mathrm{~m} \mathrm{~s}^{-1}\right)$ and at a wire angle of $45^{\circ}$. Calibrated flow meters were mounted in the mouth of each net and measured volume of water, which ranged from 202 to $835 \mathrm{~m}^{3}$ (mean $\pm \mathrm{SD} 445 \pm 112 \mathrm{~m}^{3}$ ). Each net of the Tucker trawl opened at the desired depth, and was towed for approximately $10 \mathrm{~min}$ and then closed and retrieved. The depth intervals $\left(\mathrm{d}_{\mathrm{i}}\right)$ at the DT station were every $10 \mathrm{~m}\left(\mathrm{~d}_{1}=5, \mathrm{~d}_{2}=15\right.$ and $\left.\mathrm{d}_{3}=25 \mathrm{~m}\right)$; at the MQ station every $5 \mathrm{~m}\left(\mathrm{~d}_{1}=5, \mathrm{~d}_{2}=10\right.$ and $\left.\mathrm{d}_{3}=15 \mathrm{~m}\right)$ and at ON station every $3 \mathrm{~m}\left(\mathrm{~d}_{1}=3, \mathrm{~d}_{2}=6\right.$ and $\left.\mathrm{d}_{3}=9 \mathrm{~m}\right)$. Samples were collected at each station at $2 \mathrm{~h}$ intervals. At the DT and MQ stations samples were collected for $24 \mathrm{~h}$, and at the ON station for $14 \mathrm{~h}$. Plankton sampling at the DT station began at 12:00 $\mathrm{h}$ on July 2 and continued until 10:00 h on July 3, 2004, at MQ station from 17:00 h on July 3 to 15:00 h on July 4, 2004 and at the ON station from 19:00 h on July 4 to $07: 00 \mathrm{~h}$ on July 5 , 2004. The day-night cycle in July in southern Florida is $14 \mathrm{~h}$ light/10 h dark, so 7 samples were collected during the daylight and 5 in the dark at DT and MQ stations and 2 samples during the daylight and 5 in the dark at ON station. Water column temperature and conductivity were measured with a Seabird SBE-25 CTD calibrated within 2 mo before use. The CTD casts were conducted immediately after each plankton tow from near the surface to within $2 \mathrm{~m}$ of the bottom. Salinity and density were computed from the conductivity, depth and temperature readings. 
Physical data analysis. The ADCP time series at 5 min intervals were smoothed with a low-pass filter. Hourly averaged wind speed and direction data were obtained from the Dry Tortugas-C-MAN station and data were smoothed with a $3 \mathrm{~h}$ and $24 \mathrm{~h}$ low-pass filter. Hourly tidal currents for the ON station were estimated using predicted tides software (Tides \& Currents 1999, Nobeltec Nautical). Current and wind vectors were resolved into cross-shelf, $u=$ east $(+)$ and west $(-)$, and along-shore $V=$ north $(+)$ and south $(-)$ components, with no rotation to maintain a proper orientation to the coast. The $x$-component represented flood and ebb current with flood defined as positive values and ebb negative.

Wind vectors were converted to wind stress (the force applied to the sea surface by the wind) calculated as:

$$
\tau_{(x, y)}=\rho_{\mathrm{a}} C_{\mathrm{d}}|\vec{V}|(u, v)
$$

where $\tau_{x, y}$ correspond to the cross-shelf and along shore wind stress (dynes $\mathrm{cm}^{-2}$ ), respectively, $\rho_{\mathrm{a}}$ is air density $\left(1.3 \times 10^{-3} \mathrm{~g} \mathrm{~cm}^{-3}\right), C_{\mathrm{d}}$ is a drag coefficient $(1.5$ $\left.\times 10^{-3}\right), V$ is wind velocity vector and $u$ is cross-shore and $v$ along-shore wind components.

At the MQ station, vertical density gradients, current shear and Richardson numbers (Ri) were calculated from the $24 \mathrm{~h}$ time series. Richardson numbers, which are indicators of vertical turbulent mixing, are indicative of exchange between layers. For this calculation, density gradients and gravity act as stabilizing factors, and the current shear acts as the destabilizing factor (Baines 1986). The ratio between these 2 effects (gradient) is called the Richardson number, which is a dimensionless measure given by:

$$
\mathrm{Ri}=\frac{\frac{-g}{\rho} \times \frac{\Delta \rho}{\Delta z}}{\left(\frac{\Delta u}{\Delta z}\right)^{2}+\left(\frac{\Delta v}{\Delta z}\right)^{2}}
$$

where $\mathrm{g}=$ gravity acceleration $9.8 \mathrm{~m} \mathrm{~s}^{-1}, \rho=$ density of seawater $\left(\mathrm{kg} \mathrm{m}^{-3}\right), \Delta \rho / \Delta z=$ density gradient at $1 \mathrm{~m}$ depth interval, $\Delta u(v) / \Delta z=$ current shear (cross-shore and alongshore) at $1 \mathrm{~m}$ depth interval. If Ri falls below $1 / 4$, the current shear is relatively strong, and stratification is relatively weak. When this happens the water column is unstable; billows form and produce turbulent rotors, wherein the fluid from one layer gets mixed into the other layer.

Larval data analysis. Pink shrimp larvae were sorted, identified and classified into the 3 main planktonic stages: protozoeae, myses and postlarvae (Dobkin 1961). The number of larvae at each depth $(d)$ was standardized to larval concentration $\left(\mathrm{N}_{d}=\right.$ larvae $\times$ $10^{3} \mathrm{~m}^{-3}$ ) of seawater filtered. The standardized larval concentrations $\left(\mathrm{N}_{i}\right)$ were used to compare catches of larvae among depth profiles (every $2 \mathrm{~h}$ ) at a single sta- tion. Larval abundance (larvae $\times 10^{2} \mathrm{~m}^{-2}$ ) was used to compare catches of larvae among stations:

$$
A=\sum_{i=1}^{3} \frac{\mathrm{N}_{i}}{V_{i}} \times D_{i}
$$

where $A$ is the larval abundance, $i$ is net 1, 2, 3 fished during a tow, $\mathrm{N}_{i}$ is the number of larvae in net $i, D_{i}$ is the depth interval sampled by net $i, V_{i}$ is the volume of water filtered by net $i$.

Larval concentrations were log-transformed $[\ln (x$ +1 )] and tested for normality (Shapiro-Wilks) and homogeneity of variance (Barlett's test). A 3-way ANOVA for each life stage was conducted on the dataset of natural log-transformed concentrations. Factors analyzed were depth (three levels = surface, middle and bottom layer), light (two levels = light [daytime] and no light [nighttime]), and tidal phase (two levels = ebb and flood). Residuals from the ANOVAs were tested for significant autocorrelation using the 'acf' function of SPLUS. Then the original input data for the ANOVA was filtered to remove the autocorrelation (Emery \& Thomson 1997) and the ANOVA was repeated using the filtered data as input. Filtering was accomplished by auto-regression. The filtered dataset consisted of the residuals of the auto-regression, which contained all information in the original data except the autocorrelation that was removed. Our ANOVA design was unbalanced; thus, the type III sum of squares was computed for determining significance (Underwood 1981).

The weighted mean depth (WMD) of the larvae for profile (i) was calculated at the MQ station to inspect the variation of the vertical position of larvae in the water column and identify the type of temporal pattern (diurnal or semidiurnal variation):

$$
\mathrm{WMD}_{i}=\frac{\sum_{d=1}^{3} \mathrm{~N}_{d} \times D_{z}}{\sum \mathrm{N}_{d}}
$$

$\mathrm{N}_{d}$ is the concentration of larvae at specific depth; $D_{z}$ is the mean depth of sampling. A mean WMD was calculated for each larval stage.

To evaluate the physical factors that most influenced larval concentrations at each profile we used a stepwise multiple regression model. The predictive variables used in the model were wind stress $\left(\tau_{\mathrm{x},} \tau_{\mathrm{y}}\right)$, crossshelf and along-shore currents, mean water temperature, salinity, density and turbulence as indicated by Richardson numbers (Ri).

The instantaneous larval flux $\left(\mathrm{LF}_{i d}\right)$ (larvae $\mathrm{m}^{-2} \mathrm{~s}^{-1}$ ) was calculated for each larval stage to understand how larvae were transported. Onshore transport depends on the quantity of organisms present in a given water parcel and the magnitude and direction of the flow to which they are subjected (Yannicelli et al. 2006). The LF was defined as the product of the instantaneous 
larval concentration $\left(\mathrm{N}_{i d}\right)$ at each depth $(d)$ and profile (i) by the instantaneous east to west water velocity $\left(U_{i d}\right.$, $\mathrm{m} \mathrm{s}^{-1}$ ) at each depth $(d)$ and profile (i):

$$
\mathrm{LF}_{i d}=\mathrm{N}_{i d} \times U_{i d}
$$

The larval velocity relative to the water column (relative larval velocity) provides a quantification to understand whether LF results from net gain or loss velocity (Rowe \& Epifanio 1994). For each profile the vertically integrated larval velocity $\left(\mathrm{LV}_{i}\right)$ in $\mathrm{m} \mathrm{s}^{-1}$ was calculated by:

$$
\mathrm{LV}_{i}=\frac{\sum \mathrm{N}_{i d} \times U_{i d}}{\sum \mathrm{N}_{i d}}
$$

The east to west water velocity $\left(U_{5-10-15}\right)$ was averaged $\left(\mathrm{AV}_{i}\right)$ at each profile. The difference between the larval velocity $\left(\mathrm{LV}_{i}\right)$ and average water velocity $\left(\mathrm{AV}_{i}\right)$ resulted in the relative larval velocity $\left(R L V_{i}\right)$. If water velocity at any given time differs among depths, larvae may gain or lose velocity by concentrating at the bottom, middle or surface layers (Queiroga et al. 1997). This simple larval model takes into account the vertical migration of larvae in a stratified water column. However the model did not considerer the shear in the tidal velocity, and the vertical distribution of larvae was represented at only 3 points or depths.

\section{RESULTS}

\section{Hydrographic features}

Dry Tortugas station (DT) - Vertical stratification

Time-depth series of temperature at the DT station located at a depth of $30 \mathrm{~m}$ indicated strong stratification. A sharp and relatively deep thermocline was located between 15 and $22 \mathrm{~m}$ (Fig. 2A). Above and below the thermocline the variations of temperature were minimal, ca. $29.5^{\circ} \mathrm{C}$ in the upper layer and ca. $25^{\circ} \mathrm{C}$ in the lower layer. Salinity and density had a similar pattern with high gradients between 15 and $22 \mathrm{~m}$ (Fig. 2B,C). Time series of current components ( $u$ and $v)$ did not indicate changes in direction or speed throughout the water column (Fig. 3). Cross-shelf currents were higher in magnitude (from +40 to $-60 \mathrm{~cm}$ $\mathrm{s}^{-1}$ ) than along-shore currents $\left(+30\right.$ to $\left.-40 \mathrm{~cm} \mathrm{~s}^{-}\right)$. Cross-shelf currents in the upper layer (3 to $8 \mathrm{~m}$ ) were only slightly stronger than near-bottom (20 to $25 \mathrm{~m}$ ) currents. Cross-shore and along-shore current data indicated the presence of mixed tides. In the cross-shelf, semidiurnal periodicity was evident with changes of current direction about every $6 \mathrm{~h}$, and in the alongshore, currents showed a diurnal periodicity with a northward flow centered in the middle of the night.
Marquesas station (MQ) — Internal tides

Time-depth series of temperature at the MQ station located at a depth of $20 \mathrm{~m}$ revealed a shallow thermocline located in the upper layer (Fig. 2D). The thermocline, halocline and pycnocline were located in the upper $8 \mathrm{~m}$. Temperature and salinity data indicated that the depth of the thermocline and pycnocline moved up and down with the warmest isotherm $\left(27.8^{\circ} \mathrm{C}\right)$ and freshest isohaline (36.24) intersecting at the sea surface at periodic intervals (Fig. 2E,F). These oscillations occurred about every $12 \mathrm{~h}$ in synchronization with the frequency of semidiurnal tides. Water temperature was stratified vertically; in the upper layer the mean temperature was $27.5^{\circ} \mathrm{C}$, in the middle-layer $25.6^{\circ} \mathrm{C}$ and in the lower layer $25.3^{\circ} \mathrm{C}$. The mean salinity in the upper layer was 36.27 , in the middle-layer 36.36 , and in the lower layer 36.35. Time series of currents indicated a similar speed and direction in both components (Fig. 4). The cross-shelf component had a semidiurnal periodicity, with a strong eastward flow occurring in the middle of the night and another in the middle of the day. A northward flow in the along-shore current occurred approximately every $12 \mathrm{~h}$.

Time-depth series of density, current shear, and Richardson numbers (Ri) were constructed at $1 \mathrm{~m}$ depth intervals for the MQ station (Figs. 5 \& 6). Time series of density indicated a marked stratification in the upper $10 \mathrm{~m}$ of depth with periodical oscillations (Fig. 5C). Current shear showed high values between 4 and $8 \mathrm{~m}$ in both along-shore and cross-shelf components (Fig. 5A,B). Average shear in the along-shore component at 5 and $6 \mathrm{~m}$ depth was slightly larger than in the crossshelf component (Fig. 6B). Ri numbers throughout the entire water column were low (0.1 to 1.8$)$ indicating instability in the water column that enhances turbulent vertical mixing. The highest Ri numbers occurred at the pycnocline depth and the lowest occurred sporadically above and below the pycnocline, in the wind-mixed layer and the bottom tide-mixed layer respectively (Figs. 5D \& 6C). Interestingly, low Ri numbers at the shallowest depth occurred during daylight hours, which coincided with the largest concentration of pink shrimp postlarvae in the upper layer (see Fig. 10).

Time series of average temperature and sea surface temperature at the DT (first $24 \mathrm{~h}$ ) and MQ stations (last $24 \mathrm{~h}$ ) revealed that the temperature was about $2^{\circ} \mathrm{C}$ lower at the MQ station (Fig. 7B). Similar results appeared at the temperature contours across the transect where the $27^{\circ} \mathrm{C}$ isotherm, which was located at about $20 \mathrm{~m}$ at the DT station, was near the surface at the MQ station (Fig. 8). Prevailing atmospheric conditions before and during the sampling period were relatively calm with weak east-southeasterly winds (Fig. 7C,D). The average cross-shore and along-shore 

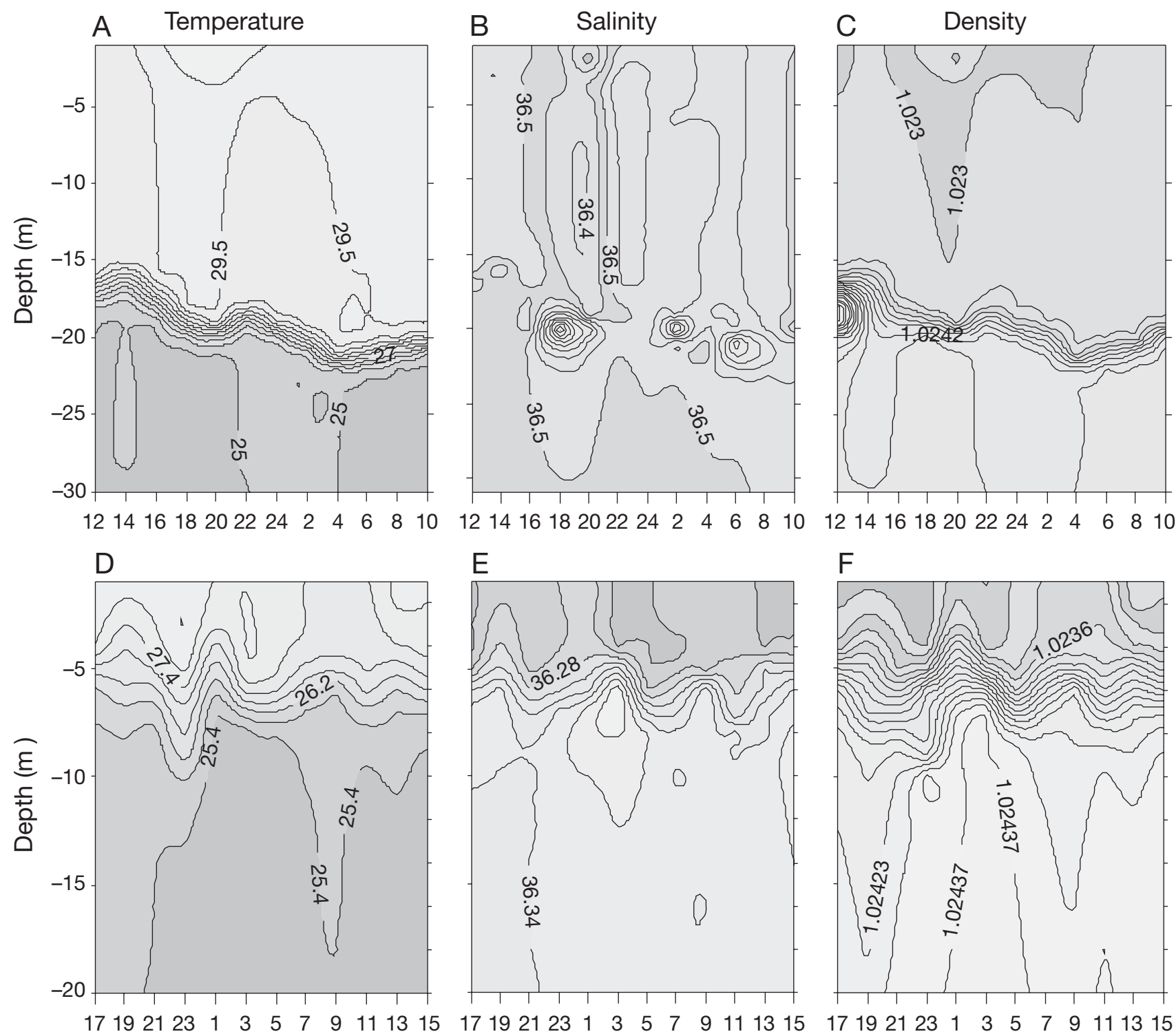

E

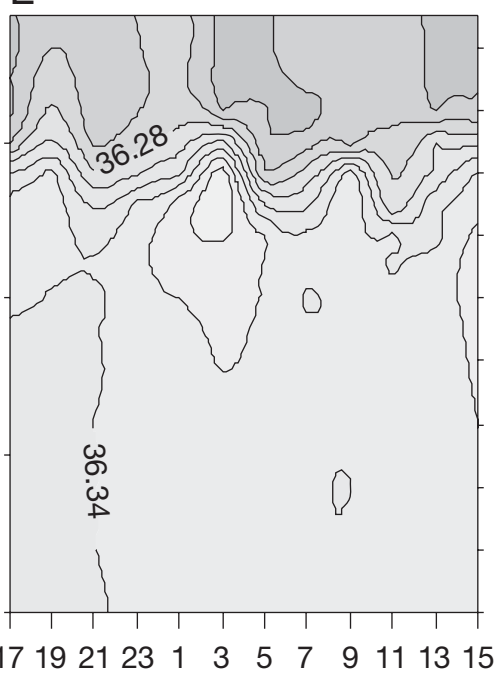

$\mathrm{F}$
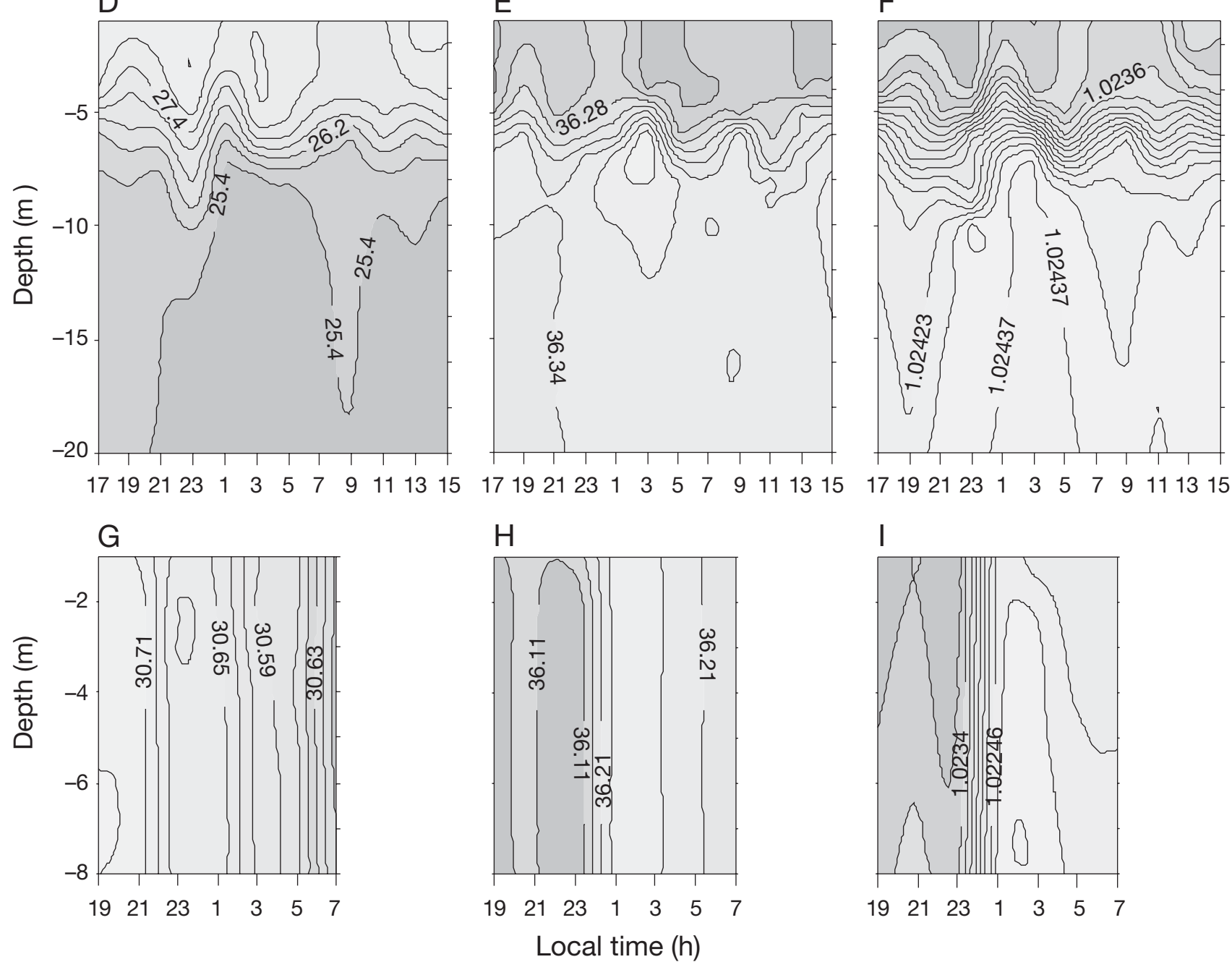

Fig. 2. Time-depth contour plots of $(\mathrm{A}, \mathrm{D}, \mathrm{G})$ temperature $\left({ }^{\circ} \mathrm{C}\right),(\mathrm{B}, \mathrm{E}, \mathrm{H})$ salinity $(\mathrm{psu})$, and $(\mathrm{C}, \mathrm{F}, \mathrm{I})$ density $\left(\mathrm{kg} \times 10^{3} \mathrm{~m}^{-3}\right)$ recorded at $2 \mathrm{~h}$ intervals at: (A-C) DT station on July 2-3, 2004, (D-F) MQ station on July 3-4, 2004 and (G-I) ON station on July 4-5, 2004 

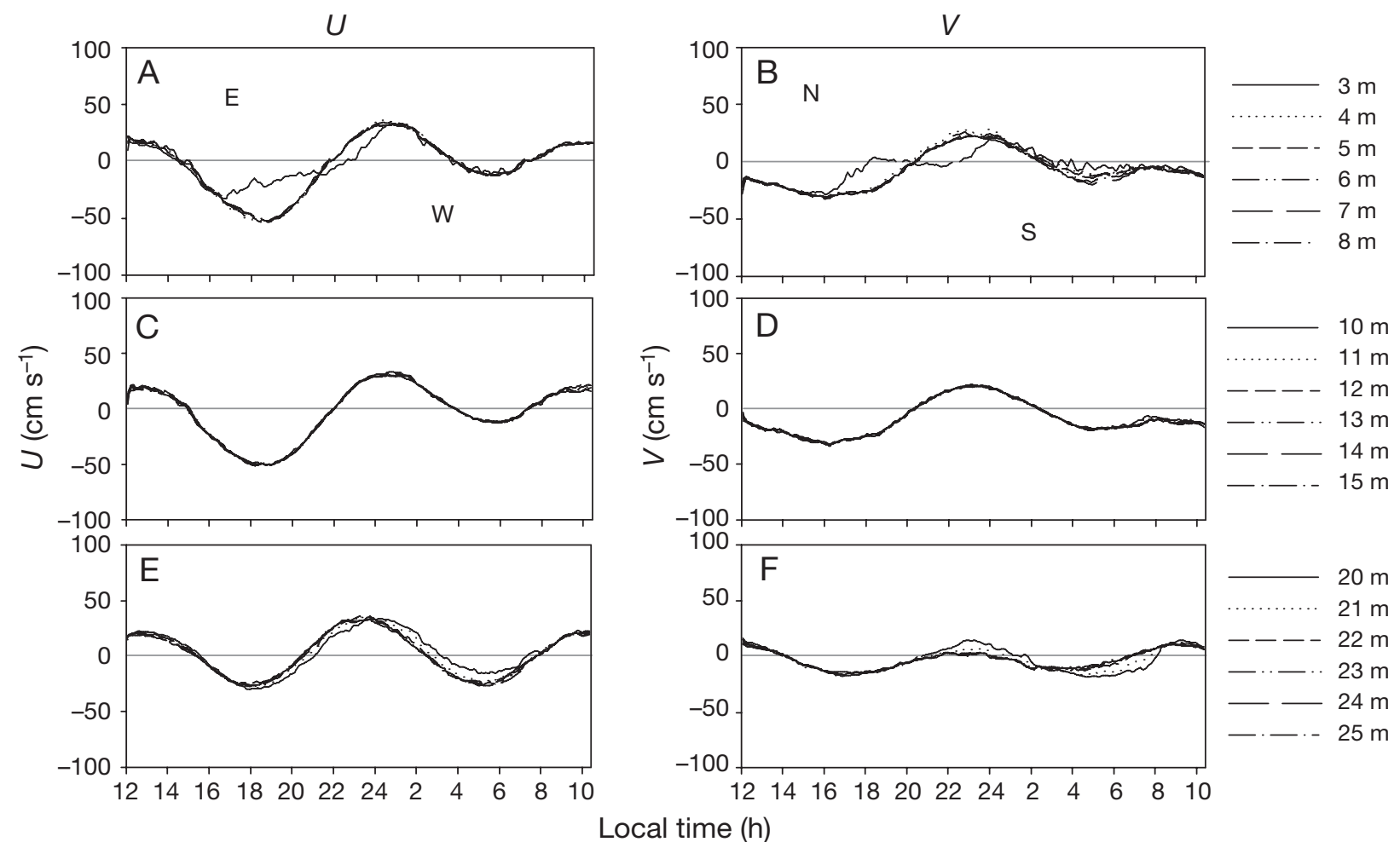

Fig. 3. Time series $(24 \mathrm{~h})$ of currents at the DT station July 2-3, 2004. (A,C,E) Cross-shelf (E-W) components $(U),(B, D, F)$ alongshore $(\mathrm{N}-\mathrm{S})$ components $(V)$. Positive values are eastward and northward, and negative values are southward and westward, respectively. (A,B) Upper layer currents (3-8 m depth), (C,D) middle-column currents (10-15 m) and (E,F) lower layer currents $(20-25 \mathrm{~m})$

$U$
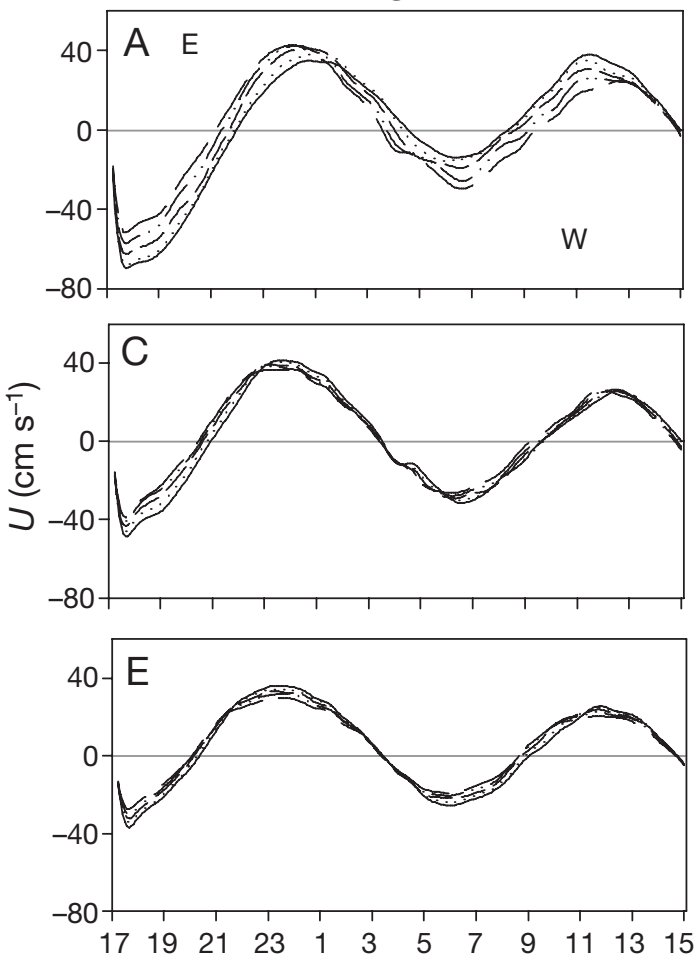

V
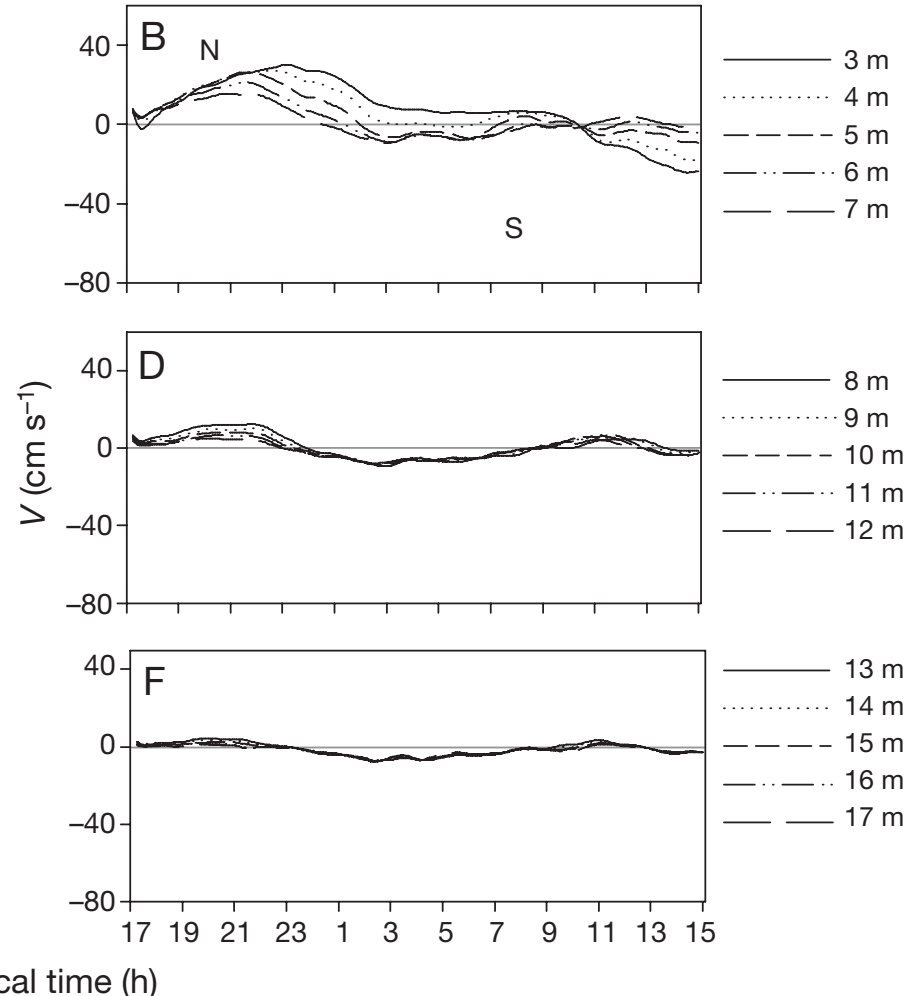

\section{Local time $(\mathrm{h})$}

Fig. 4. Time series $(24 \mathrm{~h})$ of currents at the MQ station July 3-4, 2004. (A,C,E) Cross-shelf (E-W) components $(U)$, (B,D,F) alongshore $(\mathrm{N}-\mathrm{W})$ components $(V)$. Positive values are eastward and northward, and negative values are southward and westward, respectively. (A,B) Upper layer currents (3-7 m depth), $(\mathrm{C}, \mathrm{D})$ mid-column currents $(8-12 \mathrm{~m})$ and $(\mathrm{E}, \mathrm{F})$ lower layer currents $(13-17 \mathrm{~m})$ 


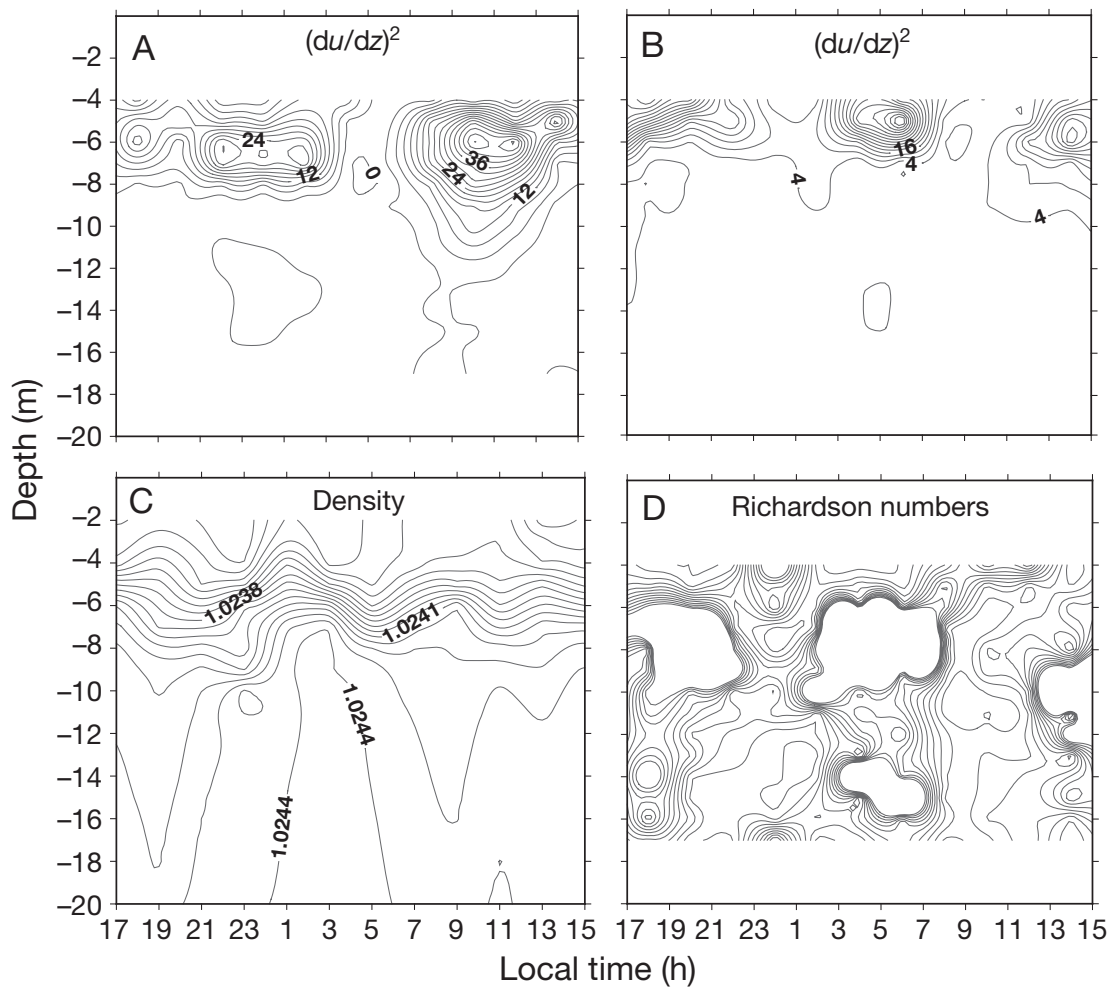

Fig. 5. Time-depth contour plots at the MQ station July 3-4, 2004: (A,B) crossshore $(\mathrm{d} u / \mathrm{d} z)^{2}$ and along-shore $(\mathrm{d} v / \mathrm{d} z)^{2}$ current shear $\left(10^{-4} \mathrm{~s}^{-2}\right)$, (C) water density $\left(\mathrm{kg} \times 10^{3} \mathrm{~m}^{-3}\right)$ and (D) Richardson numbers (Ri) showing values from 0 to 1.0. The close contour lines that appear darker and encircle blank spaces represent Ri numbers $<0.05$ and indicate instability in the water column

offshore-onshore transect indicated that larvae were concentrated at the shallow thermocline at the MQ station (Fig. 8). Larval abundances at the MQ station were about 8 times higher than those at DT station. Abundances of other decapod larvae and zooplankton biomasses were also concentrated at the shallow thermocline at MQ (M. Criales et al. unpubl.). In summary, the anomalously cool waters at the MQ station, the shallow thermocline with strong stratification and high frequency motions, and the high concentration of pink shrimp and other decapod larvae in the shallow thermocline are strong evidence of the presence of internal tides. The strong vertical shear in a weak and unstable stratified water column may provide the physical mechanisms to transport larvae from the lower layer to the upper layer, concentrating larvae at the shallow thermocline.

\section{Onshore station $(\mathrm{ON})$ - Vertical homogeneity}

The ON station was located on the inner shelf at a water depth of $10 \mathrm{~m}$.

wind stress components over the sampling period were -0.25 and 0.034 dyne $\mathrm{cm}^{-2}$, respectively. This result is consistent with the winds reported for the SWF shelf in summer (Yang \& Weisberg 1999). On July 4 the alongshore wind stress intensified and changed direction for a few hours, but with no effect on surface currents or water temperature (Fig. 7A,C).

Mean abundances of combined pink shrimp larval stages (protozoea, myses and postlarvae) across the
Time series of temperature, salinity and density indicated that the water column was vertically homogeneous (Fig. 2G-I). The temperature decreased progressively $\left(30.7\right.$ to $\left.30.5^{\circ} \mathrm{C}\right)$ during the night hours. Tidal currents continuously increased in speed from 21:00 h on July 4 to about 01:00 h on July 5 (flood tide) and continuously decreased from 01:00 h to 07:00 h (ebb tide) (see Fig. 13). Salinity and density also reflected the tidal pattern and increased during the
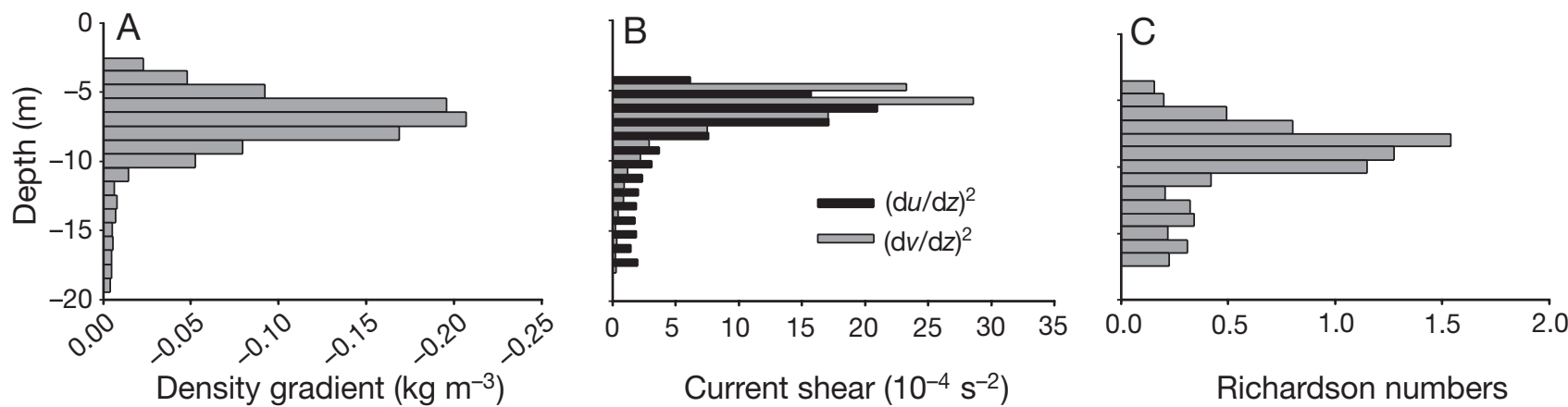

Fig. 6. (A) Mean density gradients, (B) cross-shore $(\mathrm{d} u / \mathrm{d} z)^{2}$ and along-shore $(\mathrm{d} v / \mathrm{d} z)^{2}$ current shear $\left(10^{-4} \mathrm{~s}^{-2}\right)$ and $(\mathrm{C})$ Richardson numbers, calculated every $1 \mathrm{~m}$ of depth at the MQ station, July 3-4, 2004 

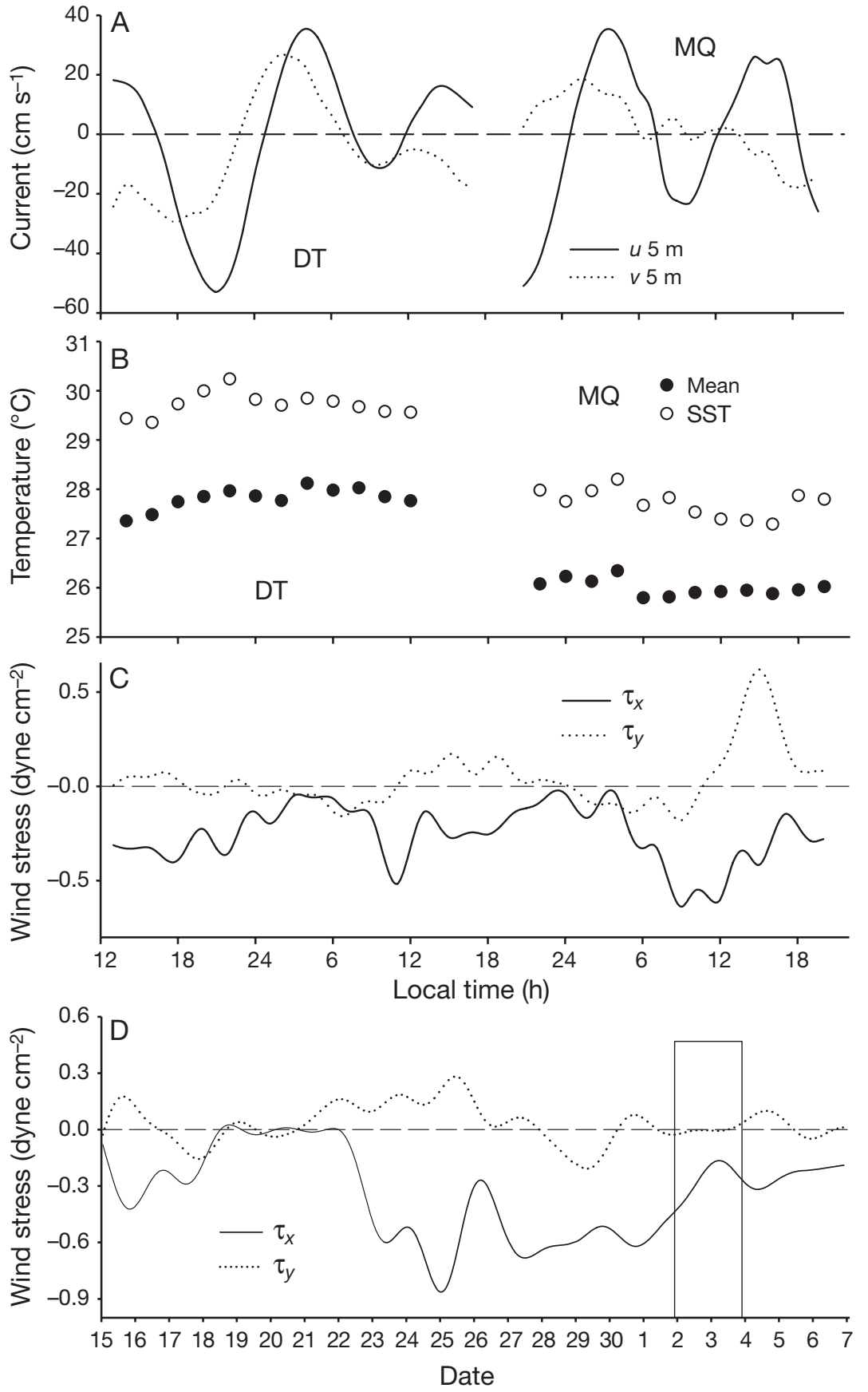

Fig. 7. (A,B) Time series at DT (first $24 \mathrm{~h}$ ) and MQ stations (last $24 \mathrm{~h}$ ): (A) upper layer currents (5 m depth), cross-shelf (E-W) component $(u)$ and along-shore $(\mathrm{N}-\mathrm{S})$ component $(\mathrm{v})$, (B) sea surface temperature (SST) at $5 \mathrm{~m}$ of depth and mean water column temperature, $(C)$ wind-stress ( $3 \mathrm{~h}$ low-pass filtered) from Dry Tortugas C-MAN station, July 2-4, 2004, cross-shelf wind stress $\tau_{x,}(\mathrm{E}-\mathrm{W})$, and alongshore wind stress $\tau_{y}(\mathrm{~N}-\mathrm{S}),(\mathrm{D})$ wind stress $(24 \mathrm{~h}$ low-pass filtered) from Dry Tortugas C-MAN station, June 15 to July 7, 2004; enclosed area represents the sampling period

first $6 \mathrm{~h}$ of flood and decreased during the next $6 \mathrm{~h}$ of ebb tide (Fig. 2H,I). Salinity increased from 36.1 to 36.26 during the flood tide and decreased from 36.26 to 36.20 during the ebb tide.

\section{Larval concentrations and distributions}

Concentrations of pink shrimp larvae at the DT station were low at all depths sampled (Fig. 9). Young protozoeae were the most abundant stages present (mean $\pm \mathrm{SD}, 2.8 \pm 5.3$ larvae $\times$ $\left.10^{3} \mathrm{~m}^{-3}\right)$; followed by myses $(1.5 \pm 1.4$ larvae $\left.\times 10^{3} \mathrm{~m}^{-3}\right)$ and postlarvae $(0.6 \pm$ 1.0 postlarvae $\times 10^{3} \mathrm{~m}^{-3}$ ). Protozoeae and myses had a similar distribution, which occurred for several hours at night and to a lesser extent (a few larvae) at mid-day. Postlarvae were observed only during the dark hours of the night. A typical diel vertical migration (DVM) was not observed for any larval stage. Day/night differences were significant for protozoeae and postlarvae (Table 1), but differences among depths were not significant for any larval stage. The majority of protozoeae were located at the deepest layer and a few moved up above the strong thermocline. Myses and postlarvae were higher in the water column than protozoeae, but they were indiscriminately distributed in the 3 depth strata. Time series of protozoeae, myses and postlarvae did not suggest a periodicity with tides. The number of larvae collected at the flood tide was slightly higher than at ebb tide, but these differences did not have any significant effect on the vertical distribution of pink shrimp larvae at this station. Since larval concentrations at the DT station were low (about 1/7 that at the MQ station), no further statistical analyses were conducted.

Distribution patterns and concentrations of pink shrimp larvae at the MQ station were different from those at the DT station. Myses were the most abundant larval stages present $(27.6 \pm 12.3$ larvae $\times 10^{3} \mathrm{~m}^{-3}, 42.1 \%$ ), followed by protozoeae $\left(22.1 \pm 14.3\right.$ larvae $\times 10^{3}$ $\left.\mathrm{m}^{-3}, 33.7 \%\right)$ and postlarvae $(15.8 \pm 14.5$ $\times$ postlarvae $10^{3} \mathrm{~m}^{-3}, 24.2 \%$ ) (Figs. $10 \&$ 11). Larval stages showed clear ontogenetic changes in vertical distribution. Young protozoeae were found deeper than myses, and myses deeper than postlarvae. These ontogenetic changes were reflected in the different mean \pm SD WMD 


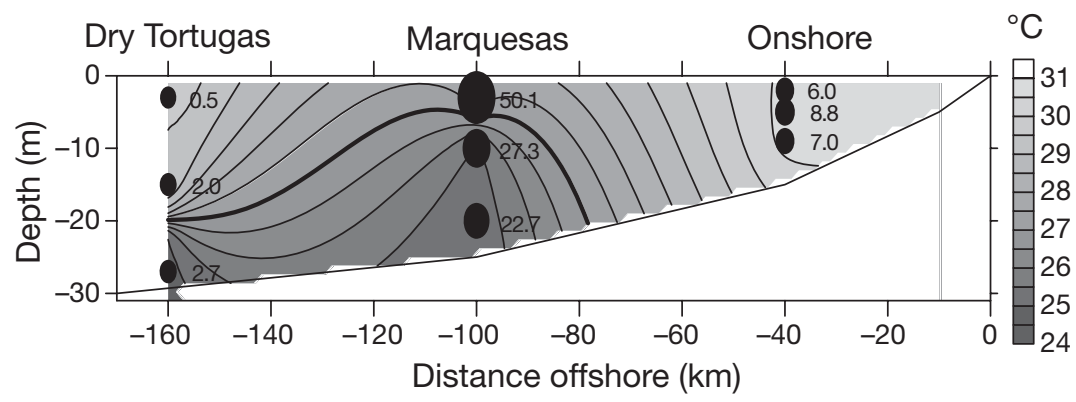

Fig. 8. Depth contour plot of temperature recorded at the 3 stations across the offshore-onshore transect, with the mean concentrations of larvae (labelled circles) of Farfantepenaeus duorarum superimposed on temperature contours. Mean concentrations (larvae $\times 10^{3} \mathrm{~m}^{-3}$ ) are proportional to the size of the circles; temperatures ranged from 24 to $31^{\circ} \mathrm{C}$ and the $27^{\circ} \mathrm{C}$ isotherm is shown as thicker line

among stages: $8.1 \pm 2.3 \mathrm{~m}$ for protozoeae, $5.9 \pm 1.4 \mathrm{~m}$ for myses and $3.8 \pm 1.2 \mathrm{~m}$ for postlarvae (Fig. 11C). Larval stages also showed marked differences in periodicities. A DVM was evident for protozoeae, which were concentrated at the deepest water layer during the day and at the upper layer during the night. The mean \pm $\mathrm{SD}$ WMD for protozoeae was $9.3 \pm 1.4 \mathrm{~m}$ during the

\begin{abstract}
day, both at the end of the flood tide (Fig. 12). The
\end{abstract} day, both at the end of the flood tide (Fig. 12). The largest peak of postlarvae occurred during the daytime hours. ANOVA results indicated that light, depth and tidal phase had a significant effect on the vertical distribution of postlarvae (Table 2). The myses had a distribution pattern intermediate between that of protozoeae and postlarvae. The WMD indicated that myses
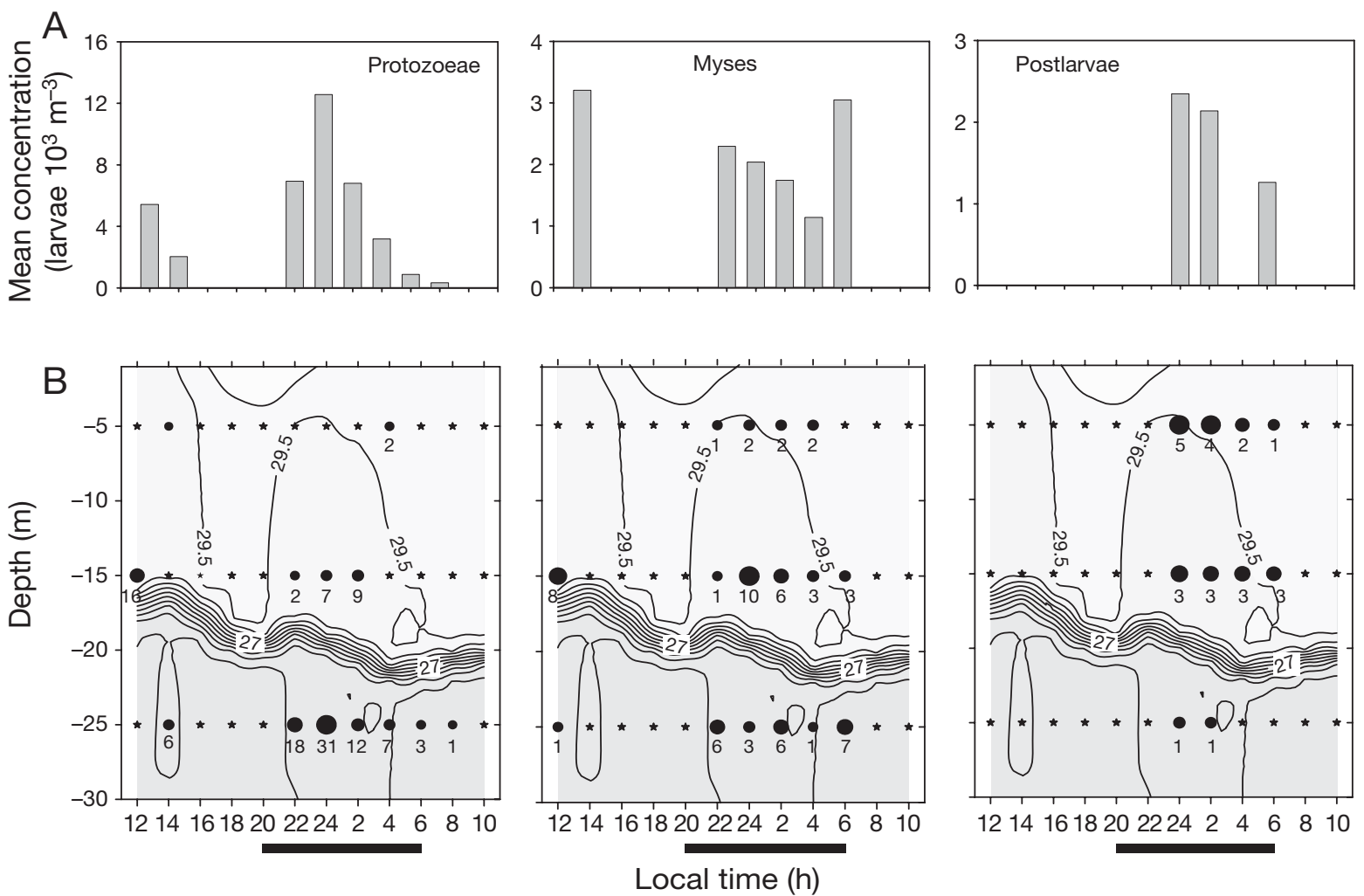

Fig. 9. Farfantepenaeus duorarum. Protozoae (left), myses (middle) and postlarvae (right) collected at the DT station on July 2-3, 2004. (A) Mean concentrations (larvae $\times 10^{3} \mathrm{~m}^{-3}$ ) at each profile every $2 \mathrm{~h}$, (B) larval concentrations (labelled circles) at 5,15 and $25 \mathrm{~m}$ depths superimposed on temperature contours. Larval concentrations ranged from 1.0 to 30.1 for protozoeae, 1.2 to 10.3 for myses and 1.2 to 4.5 for postlarvae; $\star=$ no larvae. Temperature ranged from 24 to $30^{\circ} \mathrm{C}$. Dark bars along bottom are hours of darkness 
Table 1. Farfantepenaeus duorarum. 3-way ANOVA of the effect of depth $(5,15$, and $25 \mathrm{~m})$, light (day, night), and tidal phase (flood, ebb) on the residuals from auto-regressions of log-transformed concentrations of protozoeae, myses, and postlarvae collected at DT station, July $2-3,2004 .{ }^{*} \mathrm{p}<0.05$

\begin{tabular}{|c|c|c|c|c|}
\hline Factor & $\mathrm{df}$ & MS & $F$ & $\mathrm{p}$ \\
\hline \multicolumn{5}{|l|}{ Protozoeae } \\
\hline Light (L) & 1 & 4.10 & 5.36 & $0.02^{*}$ \\
\hline Depth (D) & 2 & 2.30 & 3.01 & 0.06 \\
\hline Tide (T) & 1 & 1.90 & 2.53 & 0.12 \\
\hline $\mathrm{L} \times \mathrm{D}$ & 2 & 0.80 & 1.02 & 0.37 \\
\hline $\mathrm{L} \times \mathrm{T}$ & 1 & 2.50 & 3.23 & 0.08 \\
\hline $\mathrm{D} \times \mathrm{T}$ & 2 & 0.82 & 1.05 & 0.36 \\
\hline $\mathrm{L} \times \mathrm{D} \times \mathrm{T}$ & 2 & 0.75 & 0.97 & 0.39 \\
\hline Residuals & 26 & 0.78 & & \\
\hline \multicolumn{5}{|l|}{ Myses } \\
\hline Light (L) & 1 & 1.48 & 3.45 & 0.07 \\
\hline Depth (D) & 2 & 0.67 & 1.55 & 0.23 \\
\hline Tide (T) & 1 & 1.38 & 3.20 & 0.08 \\
\hline $\mathrm{L} \times \mathrm{D}$ & 2 & 0.46 & 1.09 & 0.35 \\
\hline $\mathrm{L} \times \mathrm{T}$ & 1 & 0.73 & 1.70 & 0.20 \\
\hline $\mathrm{D} \times \mathrm{T}$ & 2 & 0.12 & 0.27 & 0.76 \\
\hline $\mathrm{L} \times \mathrm{D} \times \mathrm{T}$ & 2 & 1.02 & 2.37 & 0.11 \\
\hline Residuals & 26 & 0.43 & & \\
\hline \multicolumn{5}{|l|}{ Postlarvae } \\
\hline Light (L) & 1 & 1.00 & 4.65 & $0.04^{*}$ \\
\hline Depth (D) & 2 & 0.20 & 0.93 & 0.41 \\
\hline Tide (T) & 1 & 0.01 & 0.06 & 0.80 \\
\hline $\mathrm{L} \times \mathrm{D}$ & 2 & 0.23 & 1.10 & 0.34 \\
\hline $\mathrm{L} \times \mathrm{T}$ & 1 & 0.18 & 0.84 & 0.36 \\
\hline $\mathrm{D} \times \mathrm{T}$ & 2 & 0.00 & 0.04 & 0.96 \\
\hline $\mathrm{L} \times \mathrm{D} \times \mathrm{T}$ & 2 & 0.00 & 0.01 & 0.98 \\
\hline Residuals & 25 & 0.21 & & \\
\hline
\end{tabular}

were concentrated in the upper layers during the daylight tidal peak, but were found also at middle and deep layer during the nocturnal tidal peak (Fig. 11C). The 2 peaks of myses in the upper layer were separated by 12 h, as with the postlarvae. Flood tide concentrations were higher than ebb tide concentrations and were of similar magnitude for both daytime and nighttime flood tides (Fig. 12). ANOVA results yielded significant differences in mysis distributions by depth strata (Table 2).

Only postlarval stages were collected at the ON station. Postlarvae were evenly distributed across the 3 depth strata (Fig. 13). The mean number \pm SD of postlarvae at the deepest $(10 \mathrm{~m})$ layer was $19.5 \pm 12.1$ postlarvae $\times 10^{3} \mathrm{~m}^{-3}$, at the middle water layer $(5 \mathrm{~m})$ was $25.4 \pm 14$ postlarvae $\times 10^{3} \mathrm{~m}^{-3}$, and at the upper layer $(3 \mathrm{~m})$ was $18.2 \pm 13.2$ postlarvae $\times 10^{3} \mathrm{~m}^{-3}$. Differences among depths were not significant (ANOVA, $F=$ $0.6052, \mathrm{p}>0.05)$. Concentrations of postlarvae were low at the beginning of the night, increased progressively during the night and reached their maximum between 23:00 and 01:00 h to start decreasing again progressively through the end of sampling early in the morning. This distribution of postlarvae resembled the tidal pattern, which reached its maximum flood tide at around 01:00 $\mathrm{h}$ and its minimum ebb tide at around 07:00 h (Fig. 13). More postlarvae were caught during the nocturnal flood tide than were caught during the nocturnal ebb tide, but differences were not significant (ANOVA, $F=0.07, \mathrm{p}>0.05$ ), and probably due to the small number of samples.

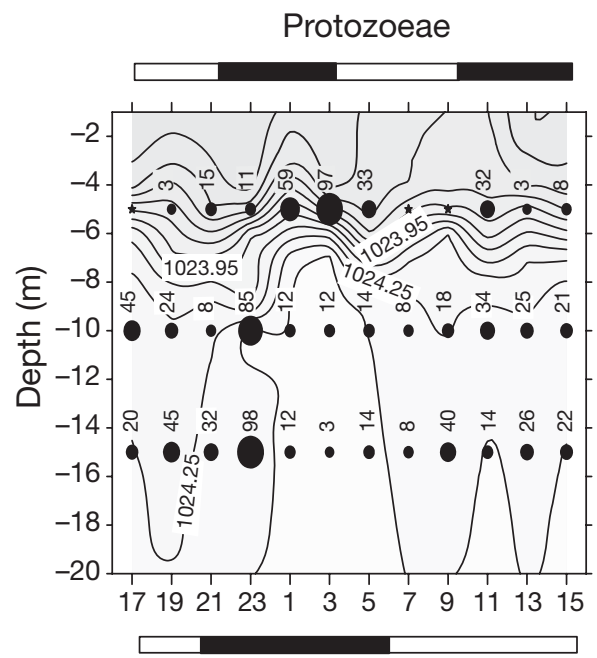

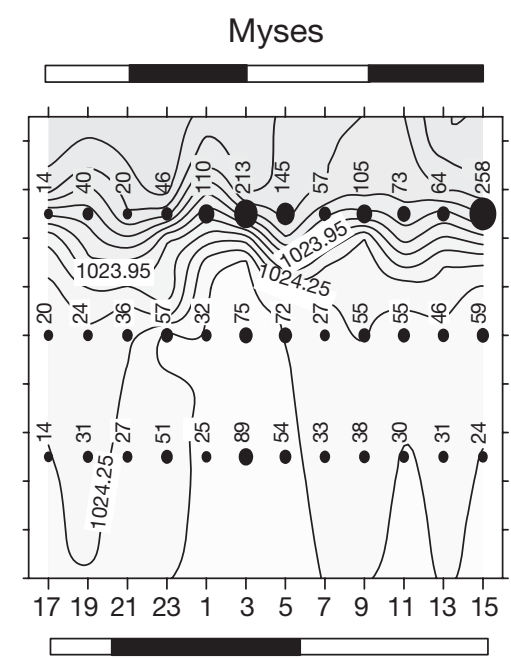

Local time (h)

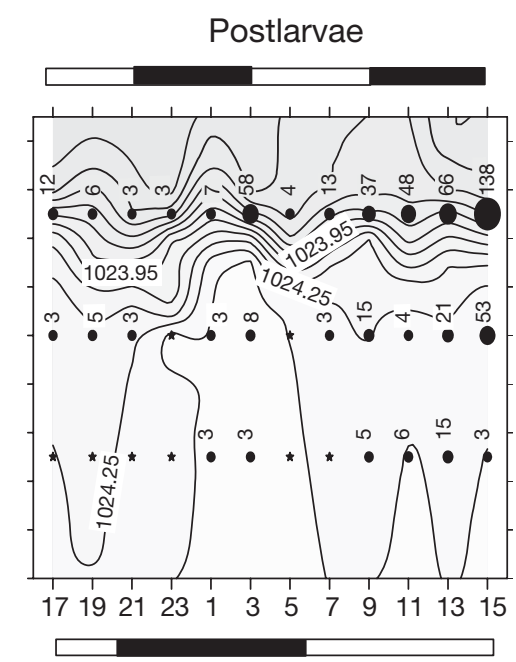

Fig. 10. Farfantepenaeus duorarum. Time-depth plots of larval concentrations (larvae $\times 10^{3} \mathrm{~m}^{-3}$ ) of protozoeae, myses and postlarvae collected at 5, 10 and $15 \mathrm{~m}$ depths at the MQ station July 3-4, 2004. Larval concentrations (labelled circles) are superimposed on density contours $\left(\mathrm{kg} \mathrm{m}^{-3}\right)$. Larval concentrations ranged from 2.6 to 98 for protozoeae, 13.9 to 257.9 for myses and 2.5 to 138.3 for postlarvae, $\star=$ no larvae. Bars on the top indicate the hours of ebb (empty) versus flood (dark); bars on the bottom represent hours of light (empty) versus darkness (dark) 


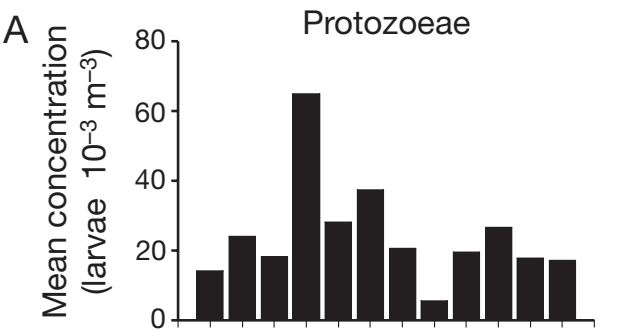

$\mathrm{B}$

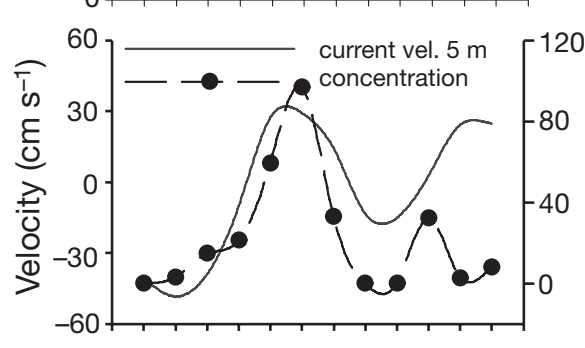

$\mathrm{C}$
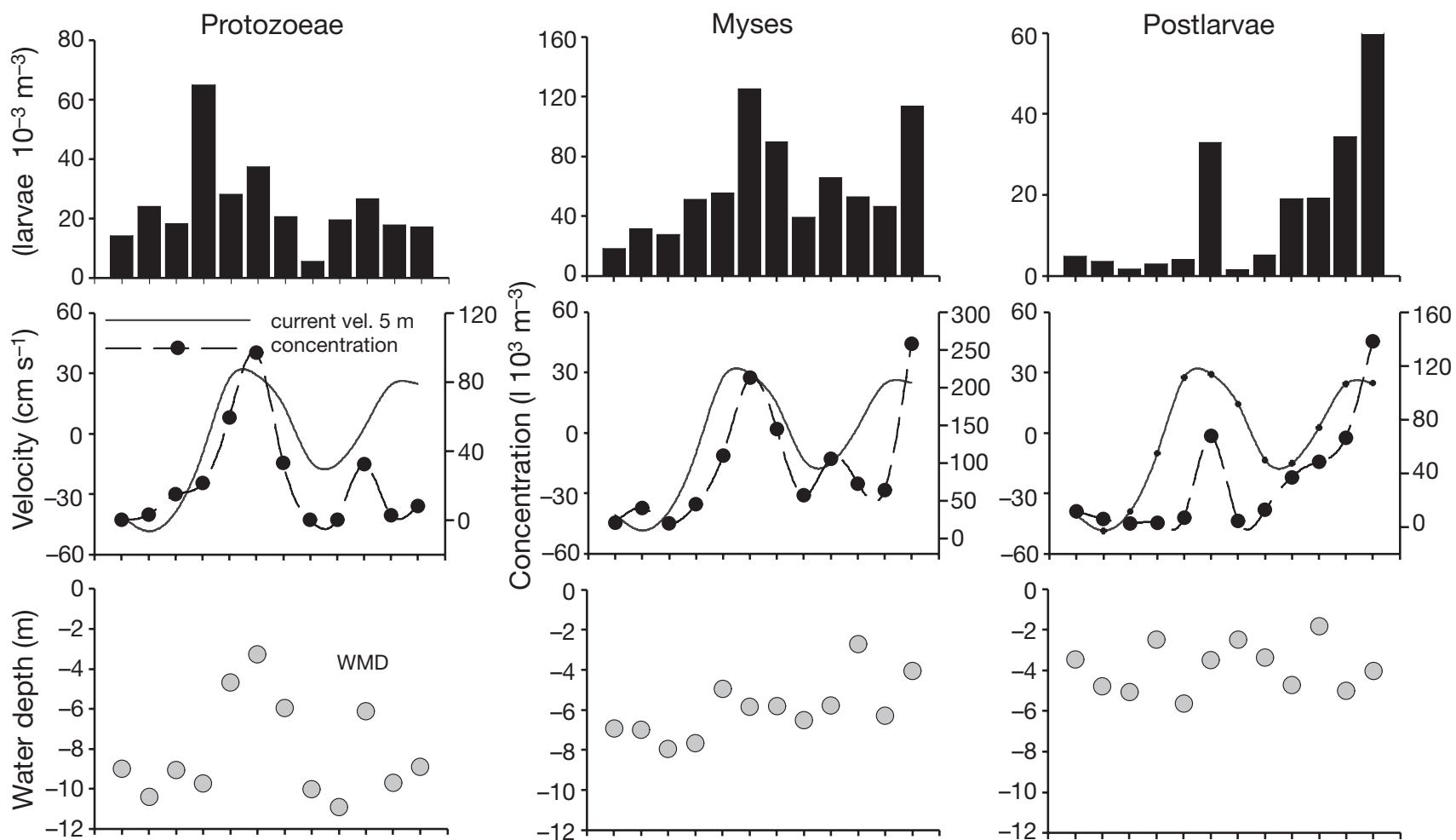

D
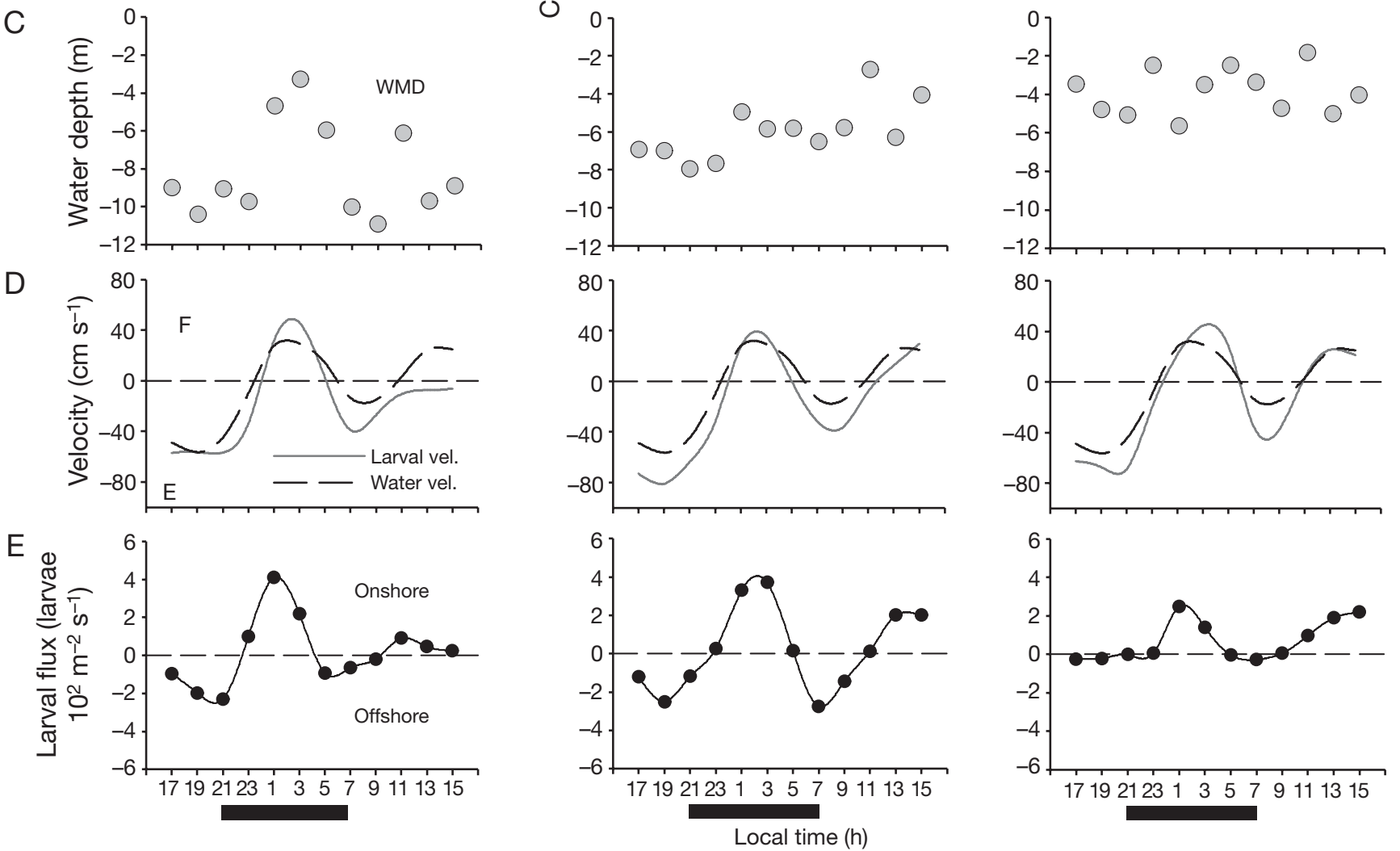

Fig. 11. Farfantepenaeus duorarum. Protozoeae (left), myses (middle) and postlarvae (right) collected at $2 \mathrm{~h}$ intervals at the MQ station, July 3-4, 2004. (A) Mean concentration (larvae $\times 10^{3} \mathrm{~m}^{-3}$ ), (B) current velocity at $5 \mathrm{~m}$ of depth with respective larval concentrations, (C) weighted mean depths (WMD), (D) mean larval and mean water column velocity, (E) larval flux. For (B), (D) and (E) positive values are eastward (flood tidal current, F) and onshore, and negative values are westward (ebb tidal current, E) and offshore. Dark bars along bottom represent hours of darkness. Vel.: velocity

\section{Larval fluxes and onshore transport}

At the MQ station high concentrations of larvae were observed during the flood tide (Fig. 11A,B), and computed instantaneous fluxes of the 3 larval stages indicated a greater influx during flood tides than during ebb tides (Fig. 11E). The larval position in the water column affected the magnitude of transport; larvae with shallower distributions were influenced by a positive relative current and a consequent onshore flux. Protozoeae that remained deeper for a longer duration (daytime hours) and occurred near the surface during 
Table 2. Farfantepenaeus duorarum. 3-way ANOVA of the effect of depth $(5,10$, and $15 \mathrm{~m})$, light (day, night), and tidal phase (flood, ebb) on the residuals from auto-regressions of log-transformed concentrations of protozoeae, myses, and postlarvae collected at MQ station, July $3-4,2004 .{ }^{*} \mathrm{p}<0.05$

\begin{tabular}{|c|c|c|c|c|}
\hline Factor & df & MS & $F$ & $\mathrm{p}$ \\
\hline \multicolumn{5}{|l|}{ Protozoeae } \\
\hline Light (L) & 1 & 3.12 & 4.26 & 0.05 \\
\hline Depth (D) & 2 & 1.25 & 1.72 & 0.20 \\
\hline Tide $(\mathrm{T})$ & 1 & 2.76 & 3.77 & 0.06 \\
\hline $\mathrm{L} \times \mathrm{D}$ & 2 & 4.51 & 6.17 & $0.00^{*}$ \\
\hline $\mathrm{L} \times \mathrm{T}$ & 1 & 0.26 & 0.36 & 0.55 \\
\hline $\mathrm{D} \times \mathrm{T}$ & 2 & 1.67 & 2.29 & 0.12 \\
\hline $\mathrm{L} \times \mathrm{D} \times \mathrm{T}$ & 2 & 0.55 & 0.75 & 0.48 \\
\hline Residuals & 23 & 0.73 & & \\
\hline \multicolumn{5}{|l|}{ Myses } \\
\hline Light (L) & 1 & 0.14 & 0.55 & 0.47 \\
\hline Depth (D) & 2 & 1.78 & 6.95 & $0.00^{*}$ \\
\hline Tide $(\mathrm{T})$ & 1 & 0.83 & 3.25 & 0.08 \\
\hline $\mathrm{L} \times \mathrm{D}$ & 2 & 0.09 & 0.37 & 0.69 \\
\hline $\mathrm{L} \times \mathrm{T}$ & 1 & 0.01 & 0.02 & 0.88 \\
\hline $\mathrm{D} \times \mathrm{T}$ & 2 & 0.20 & 0.77 & 0.47 \\
\hline $\mathrm{L} \times \mathrm{D} \times \mathrm{T}$ & 2 & 0.34 & 1.31 & 0.29 \\
\hline Residuals & 23 & 0.26 & & \\
\hline \multicolumn{5}{|l|}{ Postlarvae } \\
\hline Light (L) & 1 & 7.20 & 11.87 & $0.00^{*}$ \\
\hline Depth (D) & 2 & 13.89 & 22.91 & $0.00^{*}$ \\
\hline Tide $(\mathrm{T})$ & 1 & 6.04 & 9.97 & $0.00^{*}$ \\
\hline $\mathrm{L} \times \mathrm{D}$ & 2 & 0.23 & 0.39 & 0.68 \\
\hline $\mathrm{L} \times \mathrm{T}$ & 1 & 0.01 & 0.02 & 0.88 \\
\hline $\mathrm{D} \times \mathrm{T}$ & 2 & 0.49 & 0.81 & 0.46 \\
\hline $\mathrm{L} \times \mathrm{D} \times \mathrm{T}$ & 2 & 0.20 & 0.32 & 0.73 \\
\hline Residuals & 23 & 0.61 & & \\
\hline
\end{tabular}

the nocturnal flood experienced an offshore flow during the day and a shoreward flow during the night (Fig. 11A-E). Myses and postlarvae that appeared in the surface layer during both observed flood periods (day and night) experienced a net onshore flow during the flooding tide. Postlarvae, the shallowest dwellers, migrated up and down with a semidiurnal tidal periodicity and experienced on average the largest net onshore flux during the $24 \mathrm{~h}$ of sampling (Fig. 11C-E). Time series of instantaneous larval fluxes were sufficient in length to suggest that the temporal changes in vertical distributions of larvae greatly influenced their cross-shelf transport. Larval velocities calculated for each larval stage were compared with the mean east-west water velocity at the 3 depths of each profile (Fig. 11D). Larval velocity and water velocity curves showed similar shape and magnitude for all 3 larval stages. Larval velocities were greater than average water velocity during the flood periods, meaning that larvae were not passively transported during this period. These differences during flood periods were larger for postlarvae $\left(25.4 \pm 7 \mathrm{~cm} \mathrm{~s}^{-1}\right)$, followed by protozoeae $\left(20.8 \pm 10.4 \mathrm{~cm} \mathrm{~s}^{-1}\right)$ and myses $(12.5 \pm 8.1 \mathrm{~cm}$ $\mathrm{s}^{-1}$ ). These results were consistent with the largest vertical displacement to surface waters, which was performed by postlarvae during the flood tides.

Myses and postlarvae together comprised about $77 \%$ of the total larval concentrations at the MQ station. The 2 peaks of myses and postlarvae at the surface layer occurred in phase with the tidal currents at the end of the 2 flood tides when strong density gradients were detected (Fig. 10). A stepwise multiple regression model conducted to evaluate the predicted variables that most influence larval concentrations indicated that the mean cross-shelf current (east-west) was highly correlated with larval concentrations (Table 3). This result is consistent with the above findings of cross-shelf transport synchronized with tidal currents. The second variable selected by the model was the mean water temperature, but the correlation was not significant.

\section{DISCUSSION}

\section{Summer spawning migration}

Abundances of pink shrimp larvae at the DT station were low at all depths sampled. In contrast, abundances were about 7 times higher at the MQ than at the DT station. Previous studies on pink shrimp fecundity, planktonic stage distributions,
Fig. 12. Farfantepenaeus duorarum. Larval concentrations (mean $\pm \mathrm{SD}$ ) of protozoeae (top), myses (middle) and postlarvae (bottom) separated by tidal stages (ebb versus flood) and light conditions (day versus night) at the $\mathrm{MQ}$ station, July 3-4, 2004 


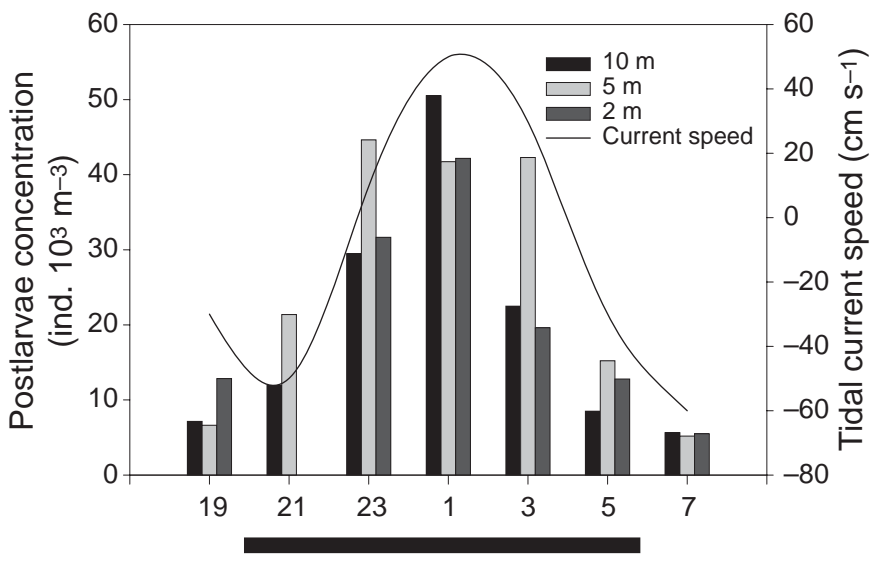

Local time (h)

Fig. 13. Farfantepenaeus duorarum. Postlarval concentrations at the ON station collected at 3 depth strata $(10,5$ and $2 \mathrm{~m})$ every 2 h, July $4-5,2004$. The mean tidal current speed for the same time period is represented on the right axis. Dark bar along bottom represents hours of darkness

and length frequencies from fishery data indicated that pink shrimp females spawn northeast of the Dry Tortugas (e.g. Munro et al. 1968, Roberts 1986). Early research also indicated that during summer months females moved into shallow waters to spawn, but the proximity to the coast of the summer migration path has not been well established (Munro et al. 1968, Jones et al. 1970). Maps of the larval distribution from this earlier research indicated that during summer the highest concentrations of protozoeae occurred about $30 \mathrm{~km}$ northeast of the Dry Tortugas at a water depth of $30 \mathrm{~m}$. This location was selected as the DT station. It was hypothesized that the summer shift may occur as a spawner avoidance response to cool bottom water temperatures associated with the vertical stratification at this time of the year (Munro et al. 1968, Jones et al. 1970); however, this hypothesis was not tested. Similar shoreward spawning migrations have been reported for other penaeid species, but the factors inducing this migration have not been determined (for review

Table 3. Farfantepenaeus duorarum. Stepwise multiple regression model of log-transformed larval concentrations (all larval stages combined) with predicted physical variables at MQ station, July 3 to 4,2004 . The physical variables listed were selected by the model using a forward selection procedure with $\mathrm{p} \leq 0.05$ to add and $\mathrm{p} \geq 0.10$ to remove. ${ }^{* *} \mathrm{p} \leq 0.001$

\begin{tabular}{|lccccc|}
\hline $\begin{array}{l}\text { Physical } \\
\text { variables }\end{array}$ & $\begin{array}{c}\text { Multiple } \\
\mathrm{R}\end{array}$ & $\begin{array}{c}\text { Cumulative } \\
\mathrm{R}^{2}\end{array}$ & $\mathrm{R}^{2}$ & $F$ & $\mathrm{p}$ \\
\hline $\begin{array}{l}\text { Cross-shelf } \\
\text { current (E-W) }\end{array}$ & 0.80 & 0.64 & 0.64 & 17.68 & $0.001^{* *}$ \\
$\begin{array}{l}\text { Water temperature } \\
\text { Water density }\end{array}$ & 0.87 & 0.75 & 0.11 & 3.97 & 0.078 \\
& 0.89 & 0.79 & 0.04 & 1.55 & 0.248 \\
\hline
\end{tabular}

see Dall et al. 1990). The water column at the DT station was vertically stratified with a strong and deep thermocline located between 15 and $22 \mathrm{~m}$ of depth (Fig. 2A). Below the thermocline the water temperature was $25^{\circ} \mathrm{C}$, a low temperature for spawning of tropical penaeid shrimps, which prefer to spawn at temperatures between $27^{\circ} \mathrm{C}$ and $29^{\circ} \mathrm{C}$ (e.g. Wenner et al. 2005). Accordingly, the low concentrations of pink shrimp larvae found at the DT station may be related to the low temperatures registered at the depth where previous authors have suggested that spawning should occur. However, the center of spawning may have shifted farther onshore at depths shallower than $30 \mathrm{~m}$ between Dry Tortugas and Marquesas. This spawning location is supported by the high concentration of pink shrimp protozoeae found near Marquesas at $20 \mathrm{~m}$ in this research and by Munro et al.'s (1968) findings on a 1964 cruise, in which the highest concentrations of pink shrimp protozoeae were immediately north and south of the Marquesas. A complete study of the reproductive dynamics of pink shrimp together with a Lagrangian transport model would help to determine the precise location of the spawning grounds, seasonality and factors that induce spawning and influence the migration of this important species.

\section{Internal tides}

The water temperature at the MQ station, which is about $60 \mathrm{~km}$ closer to shore than the Dry Tortugas, was about $2^{\circ} \mathrm{C}$ cooler than at the DT station (Figs. $7 \& 8$ ). Coldwater anomalies often occur as a result of upwelling favorable winds (Weisberg et al. 1996), cyclonic gyre circulation (Lee et al. 2002), internal tides (Baines 1986) or internal bores (Leichter et al. 1996). Winds during the sampling period were weak and mainly from the eastsoutheast, which did not favor coastal upwelling, and were consistent with the winds reported for the SWF shelf in summer (Yang \& Weisberg 1999). Cyclonic gyres are common features formed southwest of the Dry Tortugas (Lee et al. 1994), which can propagate downstream as transient coastal eddies along the edge of the Florida Keys shelf (Fratantoni et al. 1998). There are no reports of eddies moving eastward on the shallow SWF shelf in the proximity of the Marquesas, and our current data at DT did not show indications of eddy circulation. Cool anomalies at MQ do not seem to be related to either wind effects or the cyclonic circulation of eddies. On the other hand, tidal currents at MQ were strong and the water column was vertically stratified (Figs. 2A-C \& 3). The interaction between tidal currents and bottom topography in a stratified water column often results in internal tides (Vlasenko et al. 2005). At slack, internal tides are re- 
leased and progress toward the coast. If the internal tide is large enough it will eventually become asymmetrical forming internal bores and break. These internal bores propagate onshore along the thermocline affecting coastal seawater temperatures (Leichter et al. 1996, Pineda \& Lopez 2002). At the MQ station the water column was vertically stratified with a shallow thermocline and semidiurnal-like variations of the thermocline depth and strong density gradients (Figs. 2D-F \& 5). At the depth of the pycnocline Ri numbers indicated shear instability, which favors turbulent vertical mixing. All these hydrodynamic conditions are strong indications of internal tides; however, our data are insufficient to prove the presence of internal bores. This is the first study to report evidence for internal tides on the SWF shelf. Along the Florida Keys shelf internal bores have been observed as near-bottom shoreward intrusions propagating along the thermocline at depths of $30 \mathrm{~m}$ during late spring and summer (Leichter et al. 1996, 1998).

Several studies have reported high concentrations of plankton and larvae associated with internal tides and bores suggesting that these baroclinic motions may concentrate particles by their convergence currents (e.g. Shanks 1983, Witman et al. 1993). Concentrations of planktonic organisms in slicks, the ocean's visible surface manifestation of internal tides, were up to 300 times greater than concentrations outside the slicks in California waters when the slicks were oriented parallel to the coast (Shanks 1988). Those slicks most probably corresponded to the trailing side of the crest of the high frequency internal motions (Pineda 1999). Thin zooplankton layers, other features associated with internal tides, held intensive aggregations of plankton, marine snow, viruses and bacteria at the depth of the pycnocline in California waters (McManus et al. 2005). The predominant organisms found in these thin layers were mysids and euphasiids, planktonic crustaceans with elongate shapes that resemble in shape and size myses and postlarvae of penaeid shrimps. In the present study myses and postlarvae of pink shrimp were concentrated at the shallow thermocline at the MQ station during the presence of internal tides. The vertical turbulent mixing associated with the strong shear at the depth of the pycnocline may contribute to bringing larvae from the lower layer to the upper layer, assisted by a behavioral response of larvae to the environmental changes.

Onshore transport involving internal tides and bores has been demonstrated for neustonic larvae (e.g. Shanks 1983, 1988, 1998) and for larvae residing between near-bottom and the thermocline, which are transported in a sequence of phases (Pineda 1991, 1999). The mechanisms involved in the onshore transport are complex, but progress has been made in the past 2 decades in understanding these mechanisms
(Shanks 1983, 1988, 1998, Pineda 1991, 1994, 1999, Leichter et al. 1996, 1998). The presence of internal tides at MQ may indicate a potential cross-shelf transport opportunity for planktonic organisms on the inner SWF shelf. Longer time-depth series at a higher frequency of sampling and at several locations will be necessary to establish whether nonlinear dynamics (e.g. a large amplitude relative to the horizontal wavelength) characteristic of internal tidal bores prevail on some portions of the SWF shelf and contribute to the cross-shelf transport of planktonic organisms, including pink shrimp larvae.

\section{Onshore transport mechanisms and behavior}

A diel vertical migration (DVM) has been demonstrated for planktonic stages (protozoeae, myses and postlarvae) of penaeid shrimps, including the pink shrimp, during their onshore migration to the nursery grounds (e.g. Jones et al. 1970, Rothlisberg 1982), but the estimated onshore displacement with a DVM is only a few kilometers, which does not account for the more than $100 \mathrm{~km}$ that penaeid larvae have to travel to reach their nursery grounds (Rothlisberg et al. 1995). A more prolonged onshore transport can occur in association with DVM if the DVM periodicity (i.e. phase and duration) exactly matches the tidal period (semidiurnal tidal components $\mathrm{S}_{2}, \mathrm{~K}_{2}, \mathrm{M}_{2}$ ) (Hill 1991, Smith \& Stoner 1993). These conditions may produce an annual tidal coastward transport, which reach up to $70 \mathrm{~km}$ on the SWF shelf during summer months (Criales et al. 2005). Also, at the entrance to the nursery grounds postlarvae synchronize their vertical migration with the tidal currents, a type of STST that enhances onshore transport (e.g. Rothlisberg et al. 1995, Criales et al. 2006).

Results of this study indicated that pink shrimp larvae perform ontogenetic vertical migrations, in which depths of occupancy of the water column change with development; protozoeae were found deeper than myses, and myses deeper than postlarvae. Results also indicated that the youngest protozoeae performed a DVM, while myses and postlarvae occurred at the upper layer in 2 large peaks, day and night, in phase with the flood tides (Figs. 10 \& 11). Such a change of behavior from diurnal to semidiurnal began at the myses stages, which is much earlier in development than previously reported. Larval stages that synchronized their vertical migrations with the tides and had a relative shallow distribution were influenced by a positive current and consequently a large net onshore flux (Fig. 11). Postlarvae, the shallowest dwellers of the 3 planktonic stages that migrate up and down in phase with the tide, experience the largest net onshore flux. This transport mechanism, which uses differential intensity of tidal 
currents along a vertical shear gradient, is considered a generalization of the STST hypothesis (Queiroga \& Blanton 2005). Migrations during flood tides previously have been identified in postlarval penaeid shrimps, as well as in megalopae and juvenile crabs, and postlarval and juvenile estuarine fishes, during estuarine upstream migrations (for review see Forward \& Tankersley 2001). There also are a few reports of crab larvae (zoeal stages) that perform migrations during flood tide, but these migrations promote retention in estuarine areas rather than a cross-shelf transport (e.g. Dittel \& Epifanio 1990).

Diurnal and semidiurnal migrations are controlled to a large degree by behavioral responses to environmental factors (light, pressure, salinity, temperature, turbulence) (e.g. Forward et al. 1984), and responses to endogenous cycles (e.g. biological clocks or rhythms) (Forward 1989), or both. Peaks of myses and postlarvae occurred every $12 \mathrm{~h}$ in the shallow thermocline at the MQ station where strong temperature, salinity and density gradients were detected (Fig. 10). This timing was in phase with the tidal flood and consistent with the known semidiurnal tides of the area. An active swimming behavior during flood tides has been described in laboratory experiments for pink shrimp postlarvae (Hughes 1969) as well as for several megalopae crabs (Forward et al. 1984). Changes in water salinity (Hughes 1969, Mair 1980) and water pressure (Rothlisberg et al. 1995) have been proposed as the environmental factors that trigger the STST behavior in penaeid shrimp postlarvae. In laboratory experiments Hughes (1969) demonstrated that pink shrimp postlarvae were active in the water column when salinity increased and dropped to the substrate when salinity decreased. However, salinity changes in Hughes' (1969) experiment were not approximate to the salinity gradients that usually occur during the changes of tides on the SWF shelf. Changes in water pressure were investigated in laboratory experiments (Vance \& Pendrey 1997) and in simulations of transport for postlarval shrimps on the Gulf of Carpentaria, Australia (Rothlisberg et al. 1996, Condie et al. 1999). Although the response of older postlarvae to pressure was clear in laboratory experiments, a discrepancy in the timing of the behavior existed because postlarvae were more active in the ebb than the flood tide. Turbulence is another important environmental cue identified to control swimming during the STST in blue crab Callinectes sapidus megalopae (Welch \& Forward 2001). In this field study, high vertical turbulence (low Ri numbers < 0.25) was indicated at the depth of the pycnocline during the presence of internal tides, which suggests that vertical turbulence may be a possible environmental cue associated with STST behavior in penaeid larvae and postlarvae.

The importance of light in the vertical migration of pink shrimp larvae is unclear. In this study a DVM was evident for protozoeae. However, at the MQ station myses and postlarvae occurred in the water column day and night, with the highest postlarval concentration recorded at the surface during the daytime. On the other hand, at the entrance to Florida Bay, postlarvae have been collected almost exclusively during nocturnal flood tides (Criales et al. 2006), which suggests an ecological adaptation to reduce visual predation. The daytime peak of myses and postlarvae observed at a shelf station may suggest behavioral responses to environmental variables associated with both tidal currents and internal tides. A study conducted in the northwest Pacific Ocean showed that thin zooplankton layers, features associated with internal tides, persisted through the daylight hours, dissipated during evening hours and reformed again during daylight hours in phase with the nightly diel migration (McManus et al. 2005). These results support the hypothesis that internal tides could affect the concentrations of myses and postlarvae during the daytime. Alternatively, pink shrimp postlarvae may have an endogenous tidal rhythm modulated by environmental factors, but this hypothesis needs to be tested. The behavior of planktonic stages of pink shrimp needs to be studied further under controlled conditions to determine which factors are triggering the STST and define the effect of light on the vertical migration. Attention should be focused on testing the combined effects of light, temperature, salinity and turbulence on larval behavior.

Results from this research suggest that myses and early postlarvae migrated with a STST behavior at the MQ station on the SWF shelf at $\sim 20$ m of water depth and $100 \mathrm{~km}$ from Florida Bay, the main nursery ground of this species. The SWF shelf is a wide and shallow shelf dominated by tidal currents and affected by freshwater sources where planktonic pink shrimp stages may easily recognize tides (tidal currents or internal tides) by means of environmental variables. Tidal migrations have not previously been identified in migrations of decapod larvae in shelf and oceanic waters (Queiroga \& Blanton 2005), although a similar transport mechanism has been described for juveniles and adults of the holoplanktonic shrimp, Lucifer faxoni, in the northern Gulf of Mexico (Woodmansee 1966). A longer time series would be necessary to confirm if the STST is the dominant onshore transport mechanism of pink shrimp larvae and postlarvae on the SWF shelf and clarify the effect of internal tides in the cross-shelf transport.

Acknowledgements: We thank NOAA South Florida Ecosystem Restoration Prediction and Modeling (SFERPM) program for funding this study through a cooperative agreement between the Southeast Fisheries Science Center (SEFSC), Miami and CIMAS/RSMAS/University of Miami. We are 
especially grateful to W. Gandy and W. Hoggard (NOAA/ SEFSC, Pascagoula) for their valuable assistance in the logistics involved in the cruise; to all members of RV 'Gandy' crew (NOAA/SEFSC, Pascagoula) and J. Hall (NOAA/SEFSC, Miami) for their contributions to this scientific effort during the cruise; J. Wang, B. Haus and H. Peters (RSMAS/University of Miami) for valuable comments and review data; P. Ortner, S. Cummings, and J. Stamates (NOAA/AOML, Miami) for providing the ADCP; J. Schultz and C. Schroeder (NOAA/ SEFSC, Pascagoula) for providing assistance with the Tucker trawl and CTD data; T. Lee, R. Cowen, and N. Voss (RSMAS/ University of Miami) for their constructive comments and logistic support; J. Martinez, N. Melo, and J. Fiechter (RSMAS/ University of Miami) for their advice on data processing; E. Little (NOAA/Key West) for support with information on the pink shrimp fishery for the location of cruise stations and 2 anonymous reviewers for helpful comments on an earlier draft of this work.

\section{LITERATURE CITED}

Baines PG (1986) Internal tides, internal waves, and nearinternal motions. In: Mooers CNK (ed) Baroclinic processes on continental shelves. AGU, Washington, DC, p 19-31

Browder JA, Zein-Eldin Z, Criales MM, Robblee MB, Wong S, Jackson TL, Johnson D (2002) Dynamics of pink shrimp (Farfantepenaeus duorarum) recruitment potential in relation to salinity and temperature in Florida Bay. Estuaries 25:1355-1371

Condie SA, Loneragan NR, Die DJ (1999) Modelling the recruitment of tiger prawns Penaeus esculentus and $P$. semisulcatus to nursery grounds in the Gulf of Carpentaria, northern Australia: implications for assessing stock-recruitment relationships. Mar Ecol Prog Ser 178: $55-68$

Criales MM, Yeung C, Jones D, Jackson TL, Richards WJ (2003) Variation of oceanographic processes affecting the size of pink shrimp (Farfantepenaeus duorarum) postlarvae and their supply to Florida Bay. Estuar Coast Shelf Sci 57:457-468

Criales MM, Wang J, Browder JA, Robblee MB (2005) Tidal and seasonal effect of transport of pink shrimp postlarvae. Mar Ecol Prog Ser 286:231-238

Criales MM, Wang J, Browder JA, Robblee MB, Jackson TL, Hittle C (2006) Variability in supply and cross-shelf transport of pink shrimp postlarvae into western Florida Bay. Fish Bull 104:60-74

Dall W, Hill BJ, Rothlisberg PC, Staples DJ (1990) The biology of Penaeidae. Adv Mar Biol 27:1- 48

Dittel AI, Epifanio CE (1990) Seasonal and tidal abundance of crab larvae in a tropical mangrove system, Gulf of Nicoya, Costa Rica. Mar Ecol Prog Ser 65:25-34

Dobkin S (1961) Early development stages of pink shrimp, Penaeus duorarum, from Florida waters. Fish Bull 61: 321-349

Emery WJ, Thomson RE (1998) Data analysis methods in physical oceanography. Elsevier Science, Amsterdam

Epifanio CE, Garvine RW (2001) Larval transport on the Atlantic continental shelf of North America: a review. Estuar Coast Shelf Sci 52:51-77

Ewald JJ (1965) The laboratory rearing of pink shrimp, Penaeus duorarum Burkenroad. Bull Mar Sci 15:436-449

Forward RB Jr (1989) Depth regulation of larval marine decapod crustaceans: test of an hypothesis. Mar Biol 102: 195-201
Forward RB Jr, Tankersley RA (2001) Selective tidal-stream transport of marine animals. Oceanog Mar Biol 39:305-353

Forward RB Jr, Cronin TW, Steams DE (1984) Control of diel vertical migrations: photoresponses of a larval crustacean. Limnol Oceanogr 29:146-154

Forward RB Jr, Tankersley RA, Welch JM (2003) Selective tidal-stream transport of blue crab Callinectes sapidus: an overview. Bull Mar Sci 72:347-365

Fratantoni PS, Lee TN, Podesta GP, Müller-Karger F (1998) The influence of Loop Current perturbations on the formation and evolution of Tortugas eddies in the southern Straits of Florida. J Geophys Res 103 (C11):24759-24799

He R, Weisberg RH (2002) West Florida shelf circulation and temperature budget for the 1999 spring transition. Cont Shelf Res 22:719-748

Hill AE (1991) Vertical migration in tidal currents. Mar Ecol Prog Ser 75:39-54

Hughes DA (1969) Responses to salinity change as a tidal transport mechanism of pink shrimp, Penaeus duorarum Burkenroad. Biol Bull (Woods Hole) 136:45-53

Jones AC, Dimitriou DE, Ewald JJ, Tweedy JH (1970) Distribution of early developmental stages of pink shrimp, Penaeus duorarum, in Florida water. Bull Mar Sci 20:634-661

Lee TN, Williams E (1999) Mean distribution and seasonal variability of coastal currents and temperature in the Florida Keys with implications for larval recruitment. Bull Mar Sci 64:35-56

Lee TN, Clarke ME, Williams E, Szmant AF, Berger T (1994) Evolution of the Tortugas Gyre and its influence on recruitment in the Florida Keys. Bull Mar Sci 54:621-646

Lee TN, Williams E, Johns E, Wilson D, Smith NP (2002) Transport processes linking South Florida coastal ecosystems. In: Porter JW, Porter KG (eds) The Everglades, Florida Bay, and coral reefs of the Florida Keys. CRC Press, Boca Raton, FL, p 309-342

Leichter JJ, Wing SRS, Miller L, Denny MW (1996) Pulsed delivery of subthermocline water to Conch Reef (Florida Keys) by internal tidal bores. Limnol Oceanogr 41:1490-1501

Leichter JJ, Shellenbarger G, Genovese SJ, Wing SR (1998) Breaking internal waves on a Florida (USA) coral reef: a plankton pump at work? Mar Ecol Prog Ser 166:83-97

Mair JMcD (1980) Salinity and water-type preferences of four species of postlarval shrimps (Penaeus) from west Mexico. J Exp Mar Biol Ecol 45:69-82

McManus MA, Cheriton OM, Drake PJ, Holliday DV, Storlazzi CD, Donaghay PL, Greenlaw CF (2005) Effects of physical processes on structure and transport of thin zooplankton layers in the coastal ocean. Mar Ecol Prog Ser 301:199-215

Munro JL, Jones AC, Dimitriou D (1968) Abundance and distribution of the larvae of the pink shrimp (Penaeus duorarum) on the Tortugas Shelf of Florida, August 1962-October 1964. Fish Bull 67:165-181

Pineda J (1991) Predictable upwelling and the shoreward transport of planktonic larvae by internal tidal bores. Science 253:548-551

Pineda J (1994) Internal tidal bores in the near shore: warmwater fronts, seaward gravity currents and the onshore transport of neustonic larvae. J Mar Res 52:427-458

Pineda J (1999) Circulation and larval distribution in internal tidal bore warm fronts. Limnol Oceanogr 44:1400-1414

Pineda J, López M (2002) Temperature, stratification and barnacle larval settlement in two Californian sites. Cont Shelf Res 22:1183-1198

Queiroga H, Blanton J (2005) Interactions between behavior and physical forcing in the control of horizontal transport of decapod crustacean larvae. Adv Mar Biol 47:107-214 
Queiroga H, Costlow JD, Moreira MH (1997) Vertical migration of the crab Carcinus maenas first zoea in an estuary: implications for tidal stream transport. Mar Ecol Prog Ser 149:121-132

Roberts TW (1986) Abundance and distribution of pink shrimp in and around the Tortugas Sanctuary, 1981-1983. N Am J Fish Manag 6:311-327

Rothlisberg PC (1982) Vertical migration and its effect on dispersal of penaeid shrimp larvae in the Gulf of Carpentaria, Australia. Fish Bull 80:541-554

Rothlisberg PC, Church JA, Fandry C (1995) A mechanism for near-shore density and estuarine recruitment of post-larval Penaeus plebejus Hess (Decapoda, Penaeidae). Estuar Coast Shelf Sci 40:115-138

Rothlisberg PC, Craig PD, Andrewartha JR (1996) Modelling penaeid prawn larval advection in Albatross Bay, Australia: defining the effective spawning population. J Mar Freshw Res 47:157-168

Rowe PM, Epifanio CE (1994) Flux and transport of larval weakfish in Delaware Bay, USA. Mar Ecol Prog Ser 110:115-120

Shanks AL (1983) Surface slicks associated with tidally forced internal waves may transport pelagic larvae of benthic invertebrates and fishes shoreward. Mar Ecol Prog Ser 13:311-315

Shanks AL (1988) Further support for the hypothesis that internal waves can transport larvae of invertebrates and fish onshore. Fish Bull 86:703-714.

Shanks AL (1995) Mechanisms of cross-shelf dispersal of larval invertebrates and fish. In: McEdward LR (ed) Ecology of marine invertebrate larvae. CRC Press, Boca Raton, FL, p 323-367

Shanks AL (1998) Abundance of post-larval Callinectes sapidus, Penaeus spp., Uca spp., and Labinia spp. collected at an outer coastal site and their cross-shelf transport. Mar Ecol Prog Ser 168:57-69

Shanks AL (2006) Mechanisms of cross-shelf transport of crab megalopae inferred from a time series of daily abundance. Mar Biol 148:1383-1398

Smith NP (2000) Transport across the western boundary of Florida Bay. Bull Mar Sci 66:291-304

Smith NP, Stoner AW (1993). Computer simulation of larval transport through tidal channels: role of vertical migration. Estuar Coast Shelf Sci 37:43-58

Sponaugle S, Lee TN, Kourafalou V, Pinkard D (2005) Florida current frontal eddies and the settlement of coral reef fishes. Limnol Oceanogr 50:1033-1048

Editorial responsibility: Otto Kinne (Editor-in-Chief), Oldendorf/Luhe, Germany
Sulkin SD (1984) Behavioral basis of depth regulation in the larvae of brachyuran crabs. Mar Ecol Prog Ser 15:181-205

Underwood AJ (1981) Techniques of analysis of variance in experimental marine biology and ecology. Oceanogr Mar Biol Annu Rev 19:513-605

Vance DJ, Pendrey RC (1997) The definition of effective spawning stocks of commercial tiger prawns in the northern prawn fishery and king prawns in the eastern king prawn fishery-behaviour of postlarval prawns. CSIROFRDC Final Rep (Project 97/108), CSIRO Marine Research, Cleveland, Queensland

Vlasenko V, Stashchuk N, Hutter K (2005) Baroclinic tides: theoretical modeling and observational evidence. Cambridge University Press, Cambridge, UK

Weisberg RH, Black BD, Yang H (1996) Seasonal modulation of the West Florida continental shelf circulation. J Geophys Res 23:2247-2250

Welch JM, Forward RB Jr (2001) Flood tide transport of blue crab, Callinectes sapidus, postlarvae: behavioral responses to salinity and turbulence. Mar Biol 139: 911-918

Wenner EL, Knott DM, Barans CA, Wilde S, Blanton JO, Amft J (2005) Key factors influencing transport of white shrimp (Litopenaeus setiferus) post-larvae into the Ossabaw Sound system, Georgia, USA. Fish Oceanogr 14: 175-194

Witman JD, Leichter JJ, Genovese SJ, Brooks DA (1993) Pulsed phytoplankton supply to the rocky subtidal zone: influence of internal waves. Proc Natl Acad Sci 90: $1686-1690$

Woodmansee RA (1966) Daily vertical migration of Lucifer. Planktonic numbers in relation to solar and tidal cycles. Ecology 47:847-850

Yang H, Weisberg RH (1999) Response of the West-Florida continental shelf to climatological monthly mean wind forcing. J Geophys Res 104:5301-5320

Yannicelli B, Castro LR, Valle-Levinson A, Atkinson L (2006) Vertical distribution of decapod larvae in the entrance of an equatorward facing bay of central Chile: implications for transport. J Plankton Res 28:19-37

Yeung C, Jones DL, Criales MM, Jackson TL, Richards WJ (2001) Influence of coastal eddies and counter-currents on the influx of spiny lobster, Panulirus argus, postlarvae into Florida Bay: influence of eddy transport. J Mar Freshw Res 52:1217-1232

Submitted: September 1, 2006; Accepted: February 12, 2007 Proofs received from author(s): July 13, 2007 